\title{
Anti-infective Natural Products from Cyanobacteria
}

Author

Affiliation
Timo Horst Johannes Niedermeyer

German Center for Infection Research (DZIF), Partner Site Tübingen and University of Tübingen, Interfaculty Institute for Microbiology and Infection Medicine, Tübingen, Germany

Key words
cyanobacteria
anti-infective
antibacterial
antifungal
antiviral
antiprotozoal
secondary metabolites
drug discovery

- drug discovery

\section{Abstract $\nabla$}

Cyanobacteria are a promising yet underexplored source for novel natural products with potent biological activities. While predominantly cytotoxic compounds have been isolated from cyanobacteria in the past, there are also a significant number of compounds known that possess anti-infective activities. As the need for novel anti-infective lead compounds is high, this manuscript aims at giving a concise overview on the current knowledge about anti-infective secondary metabolites isolated from cyanobacteria. Antibacterial, antifungal, antiviral, antiprotozoal, and molluscicidal activities are discussed. Covering up to February 2015.

\section{Introduction}

\section{$\nabla$}

Anti-infective drugs have paved the way for modern medicine, and ended a world where the major cause of death was infectious diseases. They have been one of the important factors contributing to the rise in life expectancy in the past 75 years, and are surely the most important class of drugs in this regard $[1,2]$. The majority of anti-infective drugs in current use are based on natural products [3]. However, pharmaceutical companies have neglected both the search for novel anti-infectives and natural product-based drug discovery over many years [4], resulting in the current situation that infections with antibiotic-resistant bacteria often cannot be treated adequately [5]. Especially infections with drug-resistant gramnegative bacteria such as Pseudomonas or Enterobacter are often a serious and life-threatening condition, and only a few novel drugs are in advanced development [6]. This problem is widely acknowledged today [7-9], and pharmaceutical and biotech companies as well as public institutions have reinforced or reinstalled research in this field. This is, for example, shown by the establishment of research centers such as the German Center for Infection Research (DZIF) and the Sanofi-Fraunhofer collaboration Center for Natural Product Research as well as by the acquisition of the antibiotics specialist company Cubist Pharmaceuticals by Merck \& Co. in December 2014 and the "New Drugs for Bad Bugs" program of the Innovative Medicines Initiative (IMI) in which major pharmaceutical companies such as GlaxoSmithCline, Sanofi, AstraZeneca, Basilea, Janssen, and others as well as SMEs and public research institutes are involved.

The secondary metabolism of plants as well as microorganisms such as actinobacteria and fungi has been studied extensively over many decades, and many indispensable drug substances in many therapeutic areas have been approved that are based on compounds originally isolated from these organisms [3,10-12]. In contrast, cyanobacteria have long been neglected by natural product scientists. Until the 1980s, they were mainly known for the toxins they produce [13-15]. In recent years, however, cyanobacteria have gained more attention. They are now recognized as a promising yet underexplored source for novel natural products with potent biological activities, and several reviews covering cyanobacterial metabolites have been published [16-23]. The interest in secondary metabolites from cyanobacteria is rising ( $\bullet$ Fig. 1 ). While only about 200 cyanobacterial metabolites had been structurally characterized up until 1996 [24], this number has risen to about 1200 today [25]. However, despite the progress made in the past 15 years, this is still a small number of metabolites compared to the structures known from other microorganisms such as, e.g., the actinomycetes (> 9000 [25]). Cyanobacteria, formerly known as blue-green algae and not recognized to be bacteria, are among 


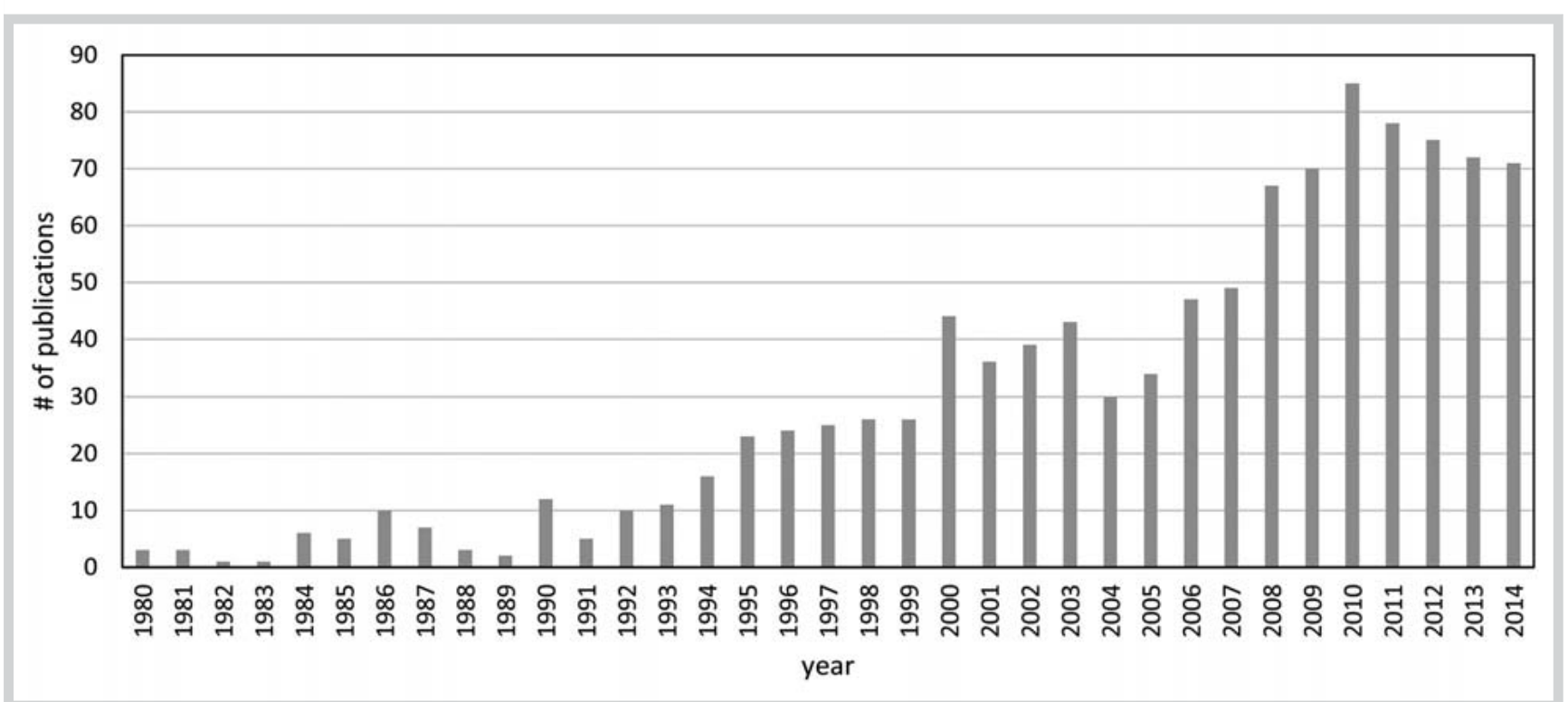

Fig. 1 SciFinder entries for "Natural product from cyanobacteri?" (09 Dec 2014).

the oldest organisms known and have been inhabiting the earth for more than three billion years [26]. They populate almost all habitats including extreme ones, and are highly diverse in terms of their morphology, physiology, and metabolism [27]. The synthesis of highly potent bioactive metabolites, in general, is one of the evolutionary strategies to cope with the dangers posed by planktivorous grazers or environmental rivals [28,29].

Burja et al. noted in 2001 that a major portion of the approximately 200 marine cyanobacterial natural products described up until 1996 displayed cytotoxic activity [16]. Indeed, cytotoxicity is still today an often-observed bioactivity of cyanobacterial secondary metabolites. The most prominent examples for cytotoxic compounds from cyanobacteria are probably the cryptophycins [30-32] and the dolastatins [33,34]. Especially the latter compounds are most interesting from a drug development point of view. Although the history of the discovery and development of the dolastatins to the drug substance Brentuximab vedotin, approved in 2011 for the treatment of patients with Hodgkin's lymphoma or with systemic anaplastic large cell lymphoma (ALCL), has been rather intricate [22], it can be said that this antibody drug conjugate is the first commercially available drug substance that is based on a cyanobacterial secondary metabolite. Cyanobacterial secondary metabolites exhibit a high chemical diversity [35]. Even though compounds from many chemical classes have been isolated, peptide and polyketide structural elements are predominant among cyanobacterial metabolites [16, $21,36]$. The peptides comprise cyclic, branched, and linear structures as well as depsipeptides, lipopeptides, and peptides with uncommon modifications such as $\mathrm{N}$ - and O-methylation, sulfation, halogenation, glycosidation, oxidation, dehydration, heterocyclization, prenylation, ketide extensions, and others [21,37]. Often, these compounds are synthesized via combined polyketide sythases and non-ribosomal peptide synthetases (PKS/ NRPS) [38-47], resulting in a high prevalence of non-proteinogenic amino acids as building blocks of these compounds. Although often not recognized at first glance, ribosomally synthesized products play an important role among bioactive metabolites from cyanobacteria as well [48-50]. Peptidic structures, especially cyclic peptides, have been postulated as "privileged structures" for bioactivities, because they have a high probability of being able to mimic peptidic substrates or ligands of endogenous proteins such as enzymes or receptors $[51,52]$.

Although PKS and NRPS genes can be detected in all cyanobacteria orders, in particular the cyanobacteria from the orders Oscillatoriales and Nostocales seem to make extensive use of PKS/ NRPS for natural product synthesis $[21,53]$. The marine cyanobacterium Moorea producens (formerly often called Lyngbya majuscula [54]) is known for a very diverse product spectrum from both a chemical and a bioactivity point of view; more than $25 \%$ of all secondary products known from cyanobacteria have been isolated from this species $[16,17,21,55,56]$.

Often, several structural variants of one parent compound are found within one strain or related strains. For example, the compound family of the microcystins comprises more than 100 natural congeners [57], and about 25 natural microginins and 140 variants of the aeruginopeptin/micropeptin/cyanopeptolin/oscillapeptin/planktopeptin family are known [25]. This facilitates both the identification of structure-activity relationships (SAR) at early research stages and the semisynthetic modification of possible lead structures. The high natural variety within the compound families is due to the variability and flexibility of the various enzymes contained in the PKS/NRPS modules discussed above as well as transposition and recombination events of biosynthesis genes ("natural combinatorial biosynthesis") [44,58]. The already high diversity of these polyketide/peptides can be even more enhanced by biocombinatorial techniques $[59,60]$.

Cyanobacteria genomes are extraordinarily large, comprising almost 10 million base pairs in the case of Nostoc punctiforme PCC 73102. A large proportion of the genome seems to be dedicated to genes encoding the biosynthetic machinery for secondary metabolites [44,61]. Given that cyanobacteria can be expected to have a biosynthetic capacity at least equal to that of other microorganisms such as myxobacteria [62], the potential of cyanobacteria for future drug discovery programs becomes clear. Indeed, the rate of rediscovery of already known compounds when working with cyanobacteria is significantly lower than for other bet- 

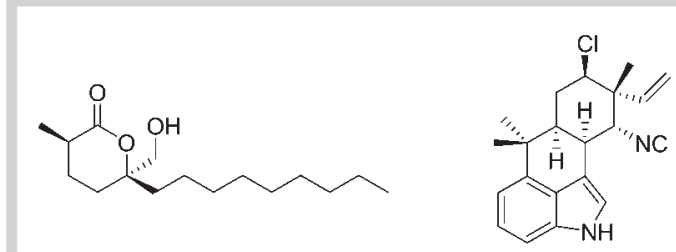

Malyngolide (1)

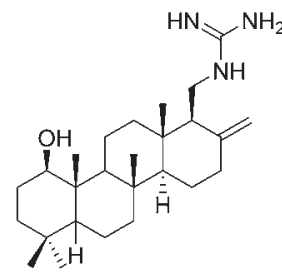

Scytoscalarol (4)

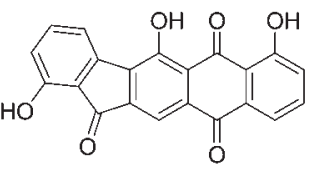

Eucapsitrione (5)

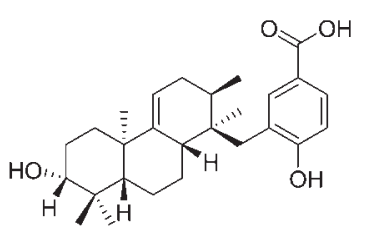

Noscomin (3)

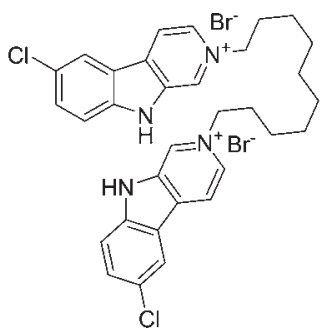

$\operatorname{NCD9}(6)$
Fig. 2 Selected cyanobacterial metabolites with antibacterial activity. ter-studied organisms $[35,63]$. The relative disregard of cyanobacteria in natural product research in the past, paired with the high chemical diversity of their secondary metabolites, makes them an attractive source of novel natural products today for pharmaceutical as well as other applications (e.g., agrochemicals, food, cosmetics).

While predominantly cytotoxic compounds have been isolated from cyanobacteria, there are also a significant number of compounds known that possess anti-infective activities. This manuscript aims at giving a concise overview on the current knowledge about anti-infective secondary metabolites isolated from cyanobacteria. Antibacterial, antifungal, antiviral, antiprotozoal, and molluscicidal activities will be covered.

\section{Antibacterial Metabolites \\ $\nabla$}

Numerous compounds with antibacterial activities have been isolated from cyanobacteria. However, only a few metabolites with specific antimicrobial activity have been found. In many cases, antimicrobial activity is associated with general cytotoxicity, thus being of limited use for further development. Few compounds have been characterized in more detail (e.g., elucidation of the mode of action) after their initial description. To the best of my knowledge, no antibacterial secondary metabolite from cyanobacteria is currently under development for this indication.

\section{Metabolites with direct antibacterial effects}

In this section, only the most interesting compounds with a direct antibacterial effect will be discussed; these are mainly compounds that have at least some specificity for antibiotic effects. A concise summary including the reported potencies of all reported compounds with antibacterial activity can be found in Table 1, the compounds discussed in the following are shown in $\bullet$ Fig. $\mathbf{2}$. The first antibiotic compound that has been described from a cyanobacterium is malyngolide (1), isolated in 1979 from a marine L. majuscula (today classified as M. producens) [64]. Subsequently, many total synthesis routes have been developed (e.g., [65-67]). Originally, the compound was described as being active against gram-positive microorganisms such as Mycobacterium smegmatis, Streptococcus pyogenes, Staphylococcus aureus, and Bacillus subtilis, and inactive against the gram-negative Salmonella enteritidis, Escherichia coli, and Pseudomonas aeruginosa. Recently, it has been found that malyngolide interferes with bacterial quorum sensing (see section "Compounds interfering with bacterial quorum sensing").

The hapalindoles are a large compound family of related indole alkaloids that were first found in Hapalosiphon species [68-70], and were later also isolated from Fischerella [71,72] and Westelliopsis [72]. Hapalindoles show activity against a range of microorganisms including S. aureus, B. subtilis, Salmonella gallinarum, and $E$. coli [73]. Interestingly, the various hapalindole congeners feature highly differing activity against a panel of microorganisms. The most potent compound, hapalindole A (2), shows MICs at sub- $\mu \mathrm{M}$ concentrations [72]. While having high antibacterial activity, they later have also been shown to be moderately cytotoxic [72] and highly insecticidal [74]. Their mode of action against eukaryotic cells is likely based on the modulation of sodium channels [75]. The ambiguine isonitrils are structurally related to the hapalindoles and have comparable bioactivity [76, 77].

Noscomin (3) and a structurally related metabolite isolated from Nostoc commune $[78,79]$ are terpenoid metabolites, a class of compounds that is rarely found to be produced by cyanobacteria. Noscomin was found to be active against Bacillus cereus, Staphylococcus epidermidis, and to a lesser extend against $E$. coli. It has not been described whether the compound has also been tested for other activities. Chemically closely related and of similar bioactivity are the comnostins isolated from the same Nostoc strain [80]. Another antibacterial terpenoid is the guanidine-sesterterpene scytoscalarol (4) from Scytonema sp. [81], again being more active against the gram-positive Bacillus anthracis and $S$. aureus than against E. coli. The compound also showed weak activity against Mycobacterium tuberculosis. Based on in silico docking studies, its mechanism of action against the latter microorganism has been proposed to be the inhibition of the arabinosyltransferase $M t b$ EmbC [82].

Eucapsitrione (5) is an anthraquinone derivative isolated from Eucapsis sp. [83]. It was found to selectively inhibit M. tuberculosis in assays testing both the activity against fast growing and nonreplicating persistent states. The compound was inactive 
Table 1 Antibacterial and antimycobacterial compounds from cyanobacteria. Activity data are given as MIC ( $\mu \mathrm{M})$ or inhibition zone in an agar diffusion assay (mm inhibition zone at the amount of the compound applied to a disk).

\begin{tabular}{|c|c|c|c|c|c|c|}
\hline Compound & From & Structure type & Active against & $\begin{array}{l}\text { MIC/Inhibition } \\
\text { zone }\end{array}$ & Additional bioactivity/comments & Ref. \\
\hline Aeruginazole A & Microcystis sp. & cyclic peptide & B. subtilis & $2.2 \mu \mathrm{M}$ & $\begin{array}{l}\text { inactive against } E \text {. coli and S. albus; } \\
\text { also antifungal (MIC S. cerevisiae } \\
43 \mu \mathrm{M}) \text {; cytotoxic (IC } 50 \text { of } 22- \\
41 \mu \mathrm{M} \text { ); no protease inhibition at } \\
40 \mu \mathrm{M}\end{array}$ & $\begin{array}{l}{[88,} \\
89]\end{array}$ \\
\hline Ambigol A-C & $\begin{array}{l}\text { Fischerella ambi- } \\
\text { gua }\end{array}$ & $\begin{array}{l}\text { polychlorinated } \\
\text { polyaromatic } \\
\text { phenols }\end{array}$ & B. megaterium & 8 mm@ @ $100 \mathrm{nmol}$ & $\begin{array}{l}\text { inactive against gram-negatives; in- } \\
\text { hibition of cyclooxygenase and HIV } \\
\text { reverse transcriptase; molluscicidal; } \\
\left.\text { cytotoxic (IC } \mathrm{C}_{50} \text { about } 75 \mu \mathrm{M}\right) \text {; anti- } \\
\text { algal; antitrypanosomal }\end{array}$ & $\begin{array}{l}{[90,} \\
91]\end{array}$ \\
\hline $\begin{array}{l}\text { Ambiguine } \\
\text { isonitrils }\end{array}$ & Fischerella sp. & alkaloids & $\begin{array}{l}\text { E. coli } \\
\text { S. aureus } \\
\text { B. subtilis } \\
\text { C. albicans }\end{array}$ & $\begin{array}{l}6 \mu \mathrm{M} \\
0.2 \mu \mathrm{M} \\
0.8 \mu \mathrm{M} \\
1.0 \mu \mathrm{M}\end{array}$ & $\begin{array}{l}\text { activity data of congener I; com- } \\
\text { pounds are also antifungal; most } \\
\text { congeners also moderately cytotoxic } \\
\left(\mathrm{IC}_{50} \text { around } 50-150 \mu \mathrm{M}\right)\end{array}$ & $\begin{array}{l}{[76,} \\
77]\end{array}$ \\
\hline $\begin{array}{l}\text { Bromoana- } \\
\text { indolone }\end{array}$ & $\begin{array}{l}\text { Anabaena constric- } \\
\text { ta }\end{array}$ & alkaloid & B. cereus & $530 \mu \mathrm{M}$ & $\begin{array}{l}\text { anticyanobacterial; cytotoxicity not } \\
\text { tested }\end{array}$ & [92] \\
\hline $\begin{array}{l}\text { Carbamido- } \\
\text { cyclophanes }\end{array}$ & Nostoc sp. & paracyclophanes & $\begin{array}{l}\text { M. tuberculosis } \\
\text { S. aureus } \\
\text { E. faecalis } \\
\text { S. pneumoniae }\end{array}$ & $\begin{array}{l}0.8-5.4 \mu \mathrm{M} \\
0.1-100 \mu \mathrm{M} \\
0.2-1.1 \mu \mathrm{M} \\
0.2-2 \mu \mathrm{M}\end{array}$ & $\begin{array}{l}\text { no activity against } M \text {. smegmatis, } \\
\text { A. baumannii, } E \text {. coli, } P \text {. aeruginosa, } K \text {. } \\
\text { pneumoniae; cytotoxic (IC } 50 \text { of } 0.5- \\
12 \mu \mathrm{M}) \text {; some congeners also anti- } \\
\text { fungal }\end{array}$ & $\begin{array}{l}{[93-} \\
95]\end{array}$ \\
\hline Carriebowlinol & yet unclassified & alkaloid & e.g. Vibrio sp. & $<1 \mu \mathrm{M}$ & also antifungal (MIC $<0.5 \mu \mathrm{M})$ & [96] \\
\hline Comnostins & Nostoc commune & diterpenes & $\begin{array}{l}\text { B. cereus } \\
\text { S. epidermidis } \\
\text { E. coli }\end{array}$ & $\begin{array}{l}40-300 \mu \mathrm{M} \\
10-80 \mu \mathrm{M} \\
150-300 \mu \mathrm{M}\end{array}$ & $\begin{array}{l}\text { also cytotoxic }\left(\mathrm{EC}_{50} \text { of } 1 \mu \mathrm{M}\right) \text { and } \\
\text { molluscicidal (MIC of } 50 \mu \mathrm{M})\end{array}$ & [97] \\
\hline Crossbyanol A-C & $\begin{array}{l}\text { Leptolyngbya cross- } \\
\text { byna }\end{array}$ & $\begin{array}{l}\text { polybrominated } \\
\text { polyaromatic } \\
\text { phenols }\end{array}$ & S. aureus & $3 \mu \mathrm{M}$ & $\begin{array}{l}\text { activity data of congener } B \text {; also brine } \\
\text { shrimp (congener } B \text {; } I C_{50} \text { of } 3 \mu \mathrm{M} \text { ) } \\
\text { and cytotoxicity }\left(I C_{50} \text { congener } A\right. \\
30 \mu \mathrm{M} \text {; congener } B>30 \mu \mathrm{M}) \text {; }\end{array}$ & [98] \\
\hline $\begin{array}{l}\alpha \text {-Dimorphecolic } \\
\text { and coriolic acid }\end{array}$ & Oscillatoria redekei & $\begin{array}{l}\text { unsaturated } \\
\text { hydroxy fatty } \\
\text { acids }\end{array}$ & $\begin{array}{l}\text { B. subtilis } \\
\text { M. flavus } \\
\text { S. aureus }\end{array}$ & $\begin{array}{l}2-6 \mathrm{~mm} @ \\
200 \mathrm{nmol} \\
0-9 \mathrm{~mm} @ \\
200 \mathrm{nmol} \\
2-7 \mathrm{~mm} @ \\
200 \mathrm{nmol}\end{array}$ & $\begin{array}{l}\text { activity comparable to that of linoleic } \\
\text { acid }\end{array}$ & [99] \\
\hline Eucapsitrione & Eucapsis sp. & anthraquinone & M. tuberculosis & $3-6 \mu \mathrm{M}$ & $\begin{array}{l}\text { inactive against } M \text {. smegmatis, S. aur- } \\
\text { eus, E. coli, and C. albicans at } 55 \mu \mathrm{M} \text {, } \\
\text { not cytotoxic at } 28 \mu \mathrm{M}\end{array}$ & [83] \\
\hline Hapalindoles & $\begin{array}{l}\text { Hapalosiphon fon- } \\
\text { tinalis; Fischerella } \\
\text { sp., Westelliopsis } \\
\text { sp. }\end{array}$ & indole alkaloids & $\begin{array}{l}\text { S. aureus } \\
\text { B. subtilis } \\
\text { E. coli }\end{array}$ & $\begin{array}{l}36 \mathrm{~mm} \\
30 \mathrm{~mm} \\
31 \mathrm{~mm}\end{array}$ & $\begin{array}{l}\text { activity data of congener } \mathrm{N} \text {; allelo- } \\
\text { pathic activity; moderately cytotoxic } \\
\left(\mathrm{IC}_{50}>30 \mu \mathrm{M}\right) \text {, antifungal, highly } \\
\text { insecticidal }\end{array}$ & $\begin{array}{l}{[68-} \\
74 \\
100 \\
101]\end{array}$ \\
\hline Kawaguchipeptins & $\begin{array}{l}\text { Microcystis aerugi- } \\
\text { nosa }\end{array}$ & cyclic peptides & S. aureus & $0.7 \mu \mathrm{M}$ & only tested against $S$. aureus & [102] \\
\hline Lyngbyazothrins & Lyngbya sp. & cyclic peptides & $\begin{array}{l}\text { B. subtilis } \\
\text { E. coli }\end{array}$ & $\begin{array}{l}18 \mathrm{~mm} @ 16 \mu \mathrm{mol} \\
18 \mathrm{~mm} @ 65 \mu \mathrm{mol}\end{array}$ & $\begin{array}{l}\text { activity data of congeners C/D; anti- } \\
\text { algal; also inhibit } 20 \text { S proteasome } \\
\left(\mathrm{IC}_{50} \text { of } 7-19 \mu \mathrm{M}\right)\end{array}$ & $\begin{array}{l}{[103-} \\
105]\end{array}$ \\
\hline Malyngamides & Lyngbya majuscula & fatty acid amides & $\begin{array}{l}\text { S. aureus } \\
\text { B. subtilis }\end{array}$ & $?$ & $\begin{array}{l}\text { cytotoxic }\left(\mathrm{I} \mathrm{C}_{50}<60 \mu \mathrm{M}\right) \text {; feeding } \\
\text { deterrents }\end{array}$ & $\begin{array}{l}{[106-} \\
108]\end{array}$ \\
\hline Malyngolide & Lyngbya majuscula & $\begin{array}{l}\text { fatty acid/ } \\
\delta \text {-lactone }\end{array}$ & $\begin{array}{l}\text { M. smegmatis } \\
\text { S. pyogenes } \\
\text { S. aureus } \\
\text { B. subtilis }\end{array}$ & $?$ & $\begin{array}{l}\text { also interferes with quorum sensing; } \\
\text { feeding deterrent }\end{array}$ & $\begin{array}{l}{[64,} \\
108]\end{array}$ \\
\hline Muscoride A & Nostoc muscorum & peptide alkaloid & B. subtilis & $3-6 \mathrm{~mm}$ & $\begin{array}{l}\text { amount on disc not given; inactive } \\
\text { against } E \text {. coli }\end{array}$ & $\begin{array}{l}{[109,} \\
110]\end{array}$ \\
\hline Norabietanes & $\begin{array}{l}\text { Microcoleous la- } \\
\text { custris }\end{array}$ & diterpenes & $\begin{array}{l}\text { S. aureus } \\
\text { S. epidermidis } \\
\text { S. typhi } \\
\text { V. cholerae }\end{array}$ & $\begin{array}{l}45 \mu \mathrm{M} \\
55 \mu \mathrm{M} \\
150 \mu \mathrm{M} \\
850 \mu \mathrm{M}\end{array}$ & $\begin{array}{l}\text { not active against } B \text {. subtilis/cereus, } \\
\text { E. coli, } K \text {. pneumoniae; cytotoxicity } \\
\text { not tested }\end{array}$ & [111] \\
\hline Nostocyclyne A & Nostoc sp. & polyketide & $\begin{array}{l}\text { S. aureus } \\
\text { B. subtilis }\end{array}$ & $\begin{array}{l}\text { MIC@36nmol } \\
\text { MIC@30nmol }\end{array}$ & $\begin{array}{l}\text { no activity against Staphylococcus } \\
\text { albus and E. coli; weak photosynthesis } \\
\text { inhibition }\end{array}$ & $\begin{array}{r}{[112]} \\
\text { cont }\end{array}$ \\
\hline
\end{tabular}


Table 1 Continued

\begin{tabular}{|c|c|c|c|c|c|c|}
\hline Compound & From & Structure type & Active against & $\begin{array}{l}\text { MIC/Inhibition } \\
\text { zone }\end{array}$ & Additional bioactivity/comments & Ref. \\
\hline Noscomin & Nostoc commune & diterpene & $\begin{array}{l}\text { B. cereus } \\
\text { S. epidermidis } \\
\text { E. coli }\end{array}$ & $\begin{array}{l}75 \mu \mathrm{M} \\
18 \mu \mathrm{M} \\
300 \mu \mathrm{M}\end{array}$ & cytotoxicity not tested & [97] \\
\hline $\begin{array}{l}\text { Nostocarboline } \\
\text { dimers }\end{array}$ & synthetic & alkaloid & $\begin{array}{l}\text { S. aureus } \\
\text { E. faecium } \\
\text { S. pneumonia } \\
\text { H. influenzae } \\
\text { E. coli } \\
\text { A. baumannii } \\
\text { P. aeruginosa }\end{array}$ & $\begin{array}{l}0.35-0.7 \mu \mathrm{M} \\
2.8 \mu \mathrm{M} \\
5.7 \mu \mathrm{M} \\
11.4 \mu \mathrm{M} \\
11.4 \mu \mathrm{M} \\
22.8 \mu \mathrm{M} \\
45.6 \mu \mathrm{M}\end{array}$ & $\begin{array}{l}\text { activity data of compound NCD9; } \\
\text { synthetic derivatives based on } \\
\text { nostocarboline from Nostoc; inactive } \\
\text { against } S \text {. cerevisiae and C. albicans }\end{array}$ & \\
\hline Pitipeptolides A-F & $\begin{array}{l}\text { Lyngbya majuscu- } \\
\text { la/Moorea pro- } \\
\text { ducens }\end{array}$ & $\begin{array}{l}\text { cyclic depsipep- } \\
\text { tides }\end{array}$ & M. tuberculosis & $\begin{array}{l}0-30 \mathrm{~mm} @ \\
60 \mu \mathrm{mol}\end{array}$ & $\begin{array}{l}\text { cytotoxic }\left(\mathrm{IC}_{50} 11-100 \mu \mathrm{M}\right) \text {, feeding } \\
\text { deterrents }\end{array}$ & $\begin{array}{l}{[113-} \\
115]\end{array}$ \\
\hline Schizotrin A & Schizotrix sp. & cyclic peptide & $\begin{array}{l}\text { B. subtilis } \\
\text { C. albicans }\end{array}$ & $\begin{array}{l}15 \mathrm{~mm} @ 7 \mathrm{nmol} \\
7 \mathrm{~mm} @ 13 \mathrm{nmol}\end{array}$ & $\begin{array}{l}\text { no activity against Gram-negatives; } \\
\text { also antifungal; cytotoxicity not } \\
\text { tested }\end{array}$ & [116] \\
\hline Scytoscalarol & Scytonema sp. & sesterterpene & $\begin{array}{l}\text { B. anthracis } \\
\text { S. aureus } \\
\text { E. coli } \\
\text { M. tuberculosis }\end{array}$ & $\begin{array}{l}6 \mu \mathrm{M} \\
2 \mu \mathrm{M} \\
30 \mu \mathrm{M} \\
110 \mu \mathrm{M}\end{array}$ & $\begin{array}{l}\text { also antifungal and weakly cytotoxic } \\
\left(\mathrm{IC}_{50} \text { of } 135 \mu \mathrm{M}\right)\end{array}$ & [81] \\
\hline Unidentified & diverse genera & $?$ & $\begin{array}{l}\text { various micro- } \\
\text { organisms }\end{array}$ & & & $\begin{array}{l}{[117-} \\
121]\end{array}$ \\
\hline
\end{tabular}

against M. smegmatis, S. aureus, E. coli, and the yeast Candida albicans, and also not cytotoxic in the concentrations tested.

Nostocarboline from a Nostoc species is a quaternary indole alkaloid [84]. It was found to inhibit the enzyme butyrylcholine esterase. First thought to be suitable as a lead for the treatment of Alzheimer's disease, it was soon realized that the compound or derivatives of it are also algicidal against photosynthetic organisms [85], and active against $M$. tuberculosis and the malaria parasite Plasmodium falciparum [86]. Synthetic studies on nostocarboline resulted in several nostocarboline dimers (e.g., NCD9, 6) showing activity against $S$. aureus, E. coli, or C. albicans [87].

\section{Compounds interfering with bacterial quorum sensing}

The term "quorum sensing" (QS) has been coined for inter- or intraspecies cell-to-cell communication by chemical signals in bacteria [122-124]. This mechanism enables bacteria to sense other species or their own population density, thus making it possible for individual bacteria in populations to coordinate their behavior. As, for example, biofilm formation and the production and secretion of many virulence factors are controlled by QS, inhibition of QS is currently being discussed as a novel and promising target for antibacterial therapy [125-128]. Different QS systems using specific chemical signals have been described, but the beststudied system is based on $\mathrm{N}$-acyl homoserine lactones as signaling compounds (AHLs, general structure 7, ○ Fig. 3) [125].

Although, to date, none of the typical genes encoding AHL biosynthesis have been found in cyanobacteria, and research on quorum sensing in cyanobacteria is still in its infancy, AHL-like compounds have been isolated from two strains: The first report, the isolation of N-butyryl homoserine lactone from $M$. producens, dates back to the 1970s, when it was not yet even known that AHLs were involved in bacterial communication. It is not known whether this compound is involved in QS in this cyanobacterium. Years later when awareness of bacterial communication had risen, it was found that Gloeothece sp. produces N-octanoyl homoserine lactone; the compound seems to have QS activity in this strain and is involved in carbohydrate and amino acid metabolism regulatory processes [129]. AHLs have also been reported to affect nitrogen fixation in Anabaena sp. PCC 7120 [130], which perhaps is the reason that this strain is able to produce the enzyme AHL-acylase that deactivates AHLs by opening the lactone ring mandatory for activity, and thus "detoxifies" them [131]. A possibility to interfere with QS of other bacteria, and in this way possibly helping to outcompete them, is the production of compounds inhibiting QS signaling molecules at the receptor site.

The first cyanobacterial metabolites for which inhibition of QS was observed were the tumonoic acids, isolated from Blennothrix cantharidosum [132]. Suspected to be QS-active due to their distant structural similarity to the AHLs, tumonoic acid F (8) was found to be the most active compound among the isolated congeners. It inhibits wild-type Vibrio harveyi bioluminescence with an $\mathrm{IC}_{50}$ of $62 \mu \mathrm{M}$, without affecting bacterial growth at this concentration. Interestingly, the compounds did not show cytotoxicity. However, the exact target of the compounds in the Vibrio QS machineries has not been elucidated.

Malyngolide (1), already mentioned above as an antibacterial compound, has been found in a directed screening for cyanobacteria extracts interfering with AHL-regulated violacein production of the reporter strain Chromobacterium violaceum CV017 [133]. The $\mathrm{EC}_{50}$ in this assay was determined to be $110 \mu \mathrm{M}$, while the compound had no effect on bacterial growth up to $220 \mu \mathrm{M}$. Compund 1 also blocked QS-dependent production of elastase by $P$. aeruginosa $\left(\mathrm{EC}_{50}\right.$ of $\left.10 \mu \mathrm{M}\right)$. Subsequent studies on the mode of action of 1 suggested that the compound acts by blocking the expression of lasR (a homologue of the luxR gene encoding the AHL sensing receptor protein) but does not interfere with the AHL-binding domain of the respective protein.

Malyngamide C (9) was isolated in 1985 from $L$. majuscula (M. producens) [134]. In 2010, its 8-epi-isomer was isolated from the same species, and both compounds were found to reduce AHL signaling at concentrations not inhibiting bacterial growth $\left(\mathrm{IC}_{50}\right.$ 
<smiles>[R]C([R])CC(=O)N[C@H]1CCOC1=O</smiles>

$\mathrm{R} 1=-\mathrm{H},-\mathrm{OH},=\mathrm{O}$

$\mathrm{R} 2=\operatorname{alkyl}\left(\mathrm{C}_{4}-\mathrm{C}_{18}\right)$

general structure of AHLs (7)

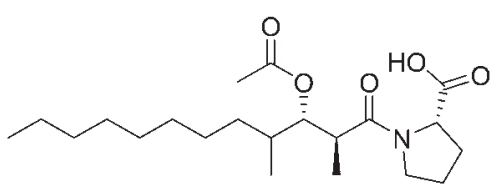

Tumonoic acid $F(8)$

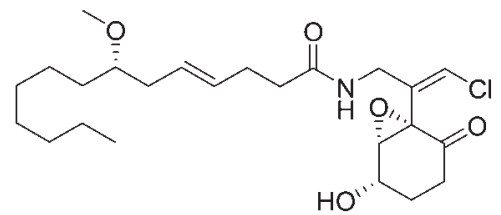

Malyngamide $C(9)$

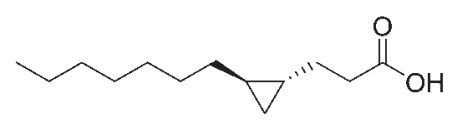

Lyngbyoic acid (10)<smiles>C=C(CCCCC)CCCC(=O)O</smiles>

Pitinoic acid (11)
Fig. 3 Cyanobacterial metabolites with quorum sensing inhibiting activity.

The hassallidins, first isolated from Tolypothrix [136,137], were found to be widespread among filamentous cyanobacteria [138]. They are structurally interesting non-ribosomal cyclic depsipeptides decorated with both a sugar and a dihydroxy fatty acid that can also be glycosylated. The MICs of hassallidins A (12) to D against various Candida species including $C$. albicans are in the range from 1.5 to $10.5 \mu \mathrm{M}[137,138]$. Cytotoxicity of the hassallidins is about 10-fold higher [139]. The balticidins A-D from Anabaena cylindrica are structurally closely related compounds with a comparable antifungal activity spectrum [140]. Interestingly, the cyclic structure does not seem to be essential for activity, as balticidins cleaved at the ester bond of the cyclic depsipeptide showed comparable bioactivity.

The laxaphycins are well-studied antifungal and cytotoxic compounds. Initially isolated from Anabaena laxa [141,142] and later also from L. majuscula/M. producens [143] and Anabaena torulosa [144], they were shown to be most active in a mixture, pointing at synergistic effects of the different laxaphycins [141]. The combination of congeners A and B had an MIC of about $20 \mu \mathrm{M}$ against Aspergillus oryzae. It is also active against other fungi such as $C$. albicans, Penicillium notatum, Saccharomyces cerevisiae, and Trichophyton mentagrophytes. However, as the cytotoxicity of this mixture is about 100-fold higher, the compounds seem of limited use to serve as antifungal lead compounds. Thus, in recent years, these compounds have been studied more from a cytotoxicity point of view, hinting at different modes of actions for laxaphycins A and B, which could already be suspected from their synergistic activity [144,145].

Majusculamide C, a metabolite isolated from L. majuscula/M. producens, has been found to be active against several plant pathogenic fungi such as Rhizoctonia solani, Pythium aphanidermatum, Aphanomyces euteiches, and Phytophthora infestans at low $\mu \mathrm{M}$ concentrations [146,147]. However, the compound was later found to also be cytotoxic at even lower, nM concentrations [148]. Cytotoxicity in addition to antifungal activity has also been observed for the scytophycins and the related tolytoxin from, e.g., Scytonema and Tolypothrix, which are the most potent antifungal compounds isolated from cyanobacteria to date [149-154]. Calophycin from Calothrix fusca is another compound with both antifungal and cytotoxic activity [155]. Tanikolide from L. majuscula/ $M$. producens, chemically related to malyngolide (1) and active against $C$. albicans, also showed brine shrimp and snail toxicity $[156,157]$. Interestingly, 1, differing from tanikolide by opposite stereochemistry and an additional methyl group at the lactone ring, showed no antifungal activity. Pronounced brine shrimp toxicity in addition to activity against $C$. albicans has also been found for lyngbyabellin B, a cyclic depsipeptide isolated from L. majuscula/M. producens [158]. Nostofungicidine from Nostoc commune has equal antifungal and cytotoxic activity (MIC of Aspergillus candidus and $\mathrm{IC}_{50}$ of NSF- 60 cells $1.5 \mu \mathrm{M}$ ) [159]. The ambiguine isonitrils and the hapalindoles have already been discussed above due to their additional antibacterial activity.

A number of antifungal compounds were described without data on cytotoxic activity:

Moderate activity against $C$. albicans (MIC of $22 \mu \mathrm{M}$ ) has been found for tolybyssidin A (13) from Tolypothrix byssoidea [160]. Fischerellin A (14) from Fischerella muscicola, a structurally interesting compound featuring an enediyne and two heterocyclic moieties, displays antialgal and herbicidal effects in addition to its antifungal activity [161].

Majusculoic acid (15), isolated from an uncharacterized cyanobacterial mat assemblage, exhibited antifungal activity against $C$. 
Table 2 Antifungal compounds from cyanobacteria. Activity data are given as MIC $(\mu \mathrm{M})$ or inhibition zone in an agar diffusion assay ( $\mathrm{mm}$ inhibition zone at the amount of the compound applied to a disk).

\begin{tabular}{|c|c|c|c|c|c|c|}
\hline Compound & From & Structure type & Active against & $\begin{array}{l}\text { MIC/Inhibition } \\
\text { zone }\end{array}$ & $\begin{array}{l}\text { Additional bioactivity/ } \\
\text { comments }\end{array}$ & Ref. \\
\hline $\begin{array}{l}\text { Ambiguine } \\
\text { isonitrils }\end{array}$ & Fischerella sp. & alkaloids & C. albicans & $1.0 \mu \mathrm{M}$ & $\begin{array}{l}\text { activity data of congener I; also anti- } \\
\text { bacterial; moderately cytotoxic }\end{array}$ & {$[76,77]$} \\
\hline Balticidins & $\begin{array}{l}\text { Anabaena cylin- } \\
\text { drica }\end{array}$ & $\begin{array}{l}\text { glycosylated } \\
\text { lipopeptide }\end{array}$ & C. maltosa & 9-18 mm@6nmol & $\begin{array}{l}\text { no antibacterial activity against } \\
\text { B. subtilis, E. coli, P. aeruginosa; } \\
\text { cytotoxicity not tested }\end{array}$ & {$[140]$} \\
\hline Calophycin & Calothrix fusca & cyclic peptide & $\begin{array}{l}\text { A. oryzae } \\
\text { C. albicans } \\
\text { P. notatum } \\
\text { S. cerevisiae } \\
\text { T. mentagro- } \\
\text { phytes }\end{array}$ & $\begin{array}{l}13 \mathrm{~mm} @ 1 \mathrm{nmol} \\
7 \mathrm{~mm} @ 1 \mathrm{nmol} \\
12 \mathrm{~mm} @ 1 \mathrm{nmol} \\
12 \mathrm{~mm} @ 1 \mathrm{nmol} \\
15 \mathrm{~mm} @ 1 \mathrm{nmol}\end{array}$ & $\begin{array}{l}\text { also cytotoxic ( } \mathrm{IC}_{50} \text { of } 0.2 \mu \mathrm{M}, \mathrm{KB} \\
\text { cells) }\end{array}$ & {$[155]$} \\
\hline Carriebowlinol & yet unclassified & alkaloid & $\begin{array}{l}\text { Fusarium sp. } \\
\text { L. thalassiae } \\
\text { D. salina }\end{array}$ & $\begin{array}{l}0.2 \mu \mathrm{M} \\
0.4 \mu \mathrm{M} \\
0.5 \mu \mathrm{M}\end{array}$ & $\begin{array}{l}\mathrm{IC}_{50} \text { given; also antibacterial against } \\
\text { several marine bacteria }(\mathrm{MIC}<1 \mu \mathrm{M})\end{array}$ & {$[96]$} \\
\hline Fischerellin A & $\begin{array}{l}\text { Fischerella musci- } \\
\text { cola }\end{array}$ & other & $\begin{array}{l}\text { U. appendicula- } \\
\text { tus } \\
\text { E. graminis }\end{array}$ & $\begin{array}{l}100 \% \text { inh. at } \\
0.6 \mathrm{mmol} \\
100 \% \text { inh. at } \\
2.5 \mathrm{mmol}\end{array}$ & also antialgal and herbicidal effects & {$[161]$} \\
\hline Hapalindoles & $\begin{array}{l}\text { Hapalosiphon } \\
\text { fontinalis }\end{array}$ & indole alkaloids & C. albicans & $0.7 \mu \mathrm{M}$ & $\begin{array}{l}\text { activity data of congener ]; also } \\
\left.\text { cytotoxic (IC } \text { IC }_{50} \text { of }-44 \mu \mathrm{M}\right) \text {, anti- } \\
\text { bacterial, highly insecticidal }\end{array}$ & {$[72]$} \\
\hline $\begin{array}{l}\text { Hassallidins } \\
\text { A and B }\end{array}$ & $\begin{array}{l}\text { Hassallia sp.; } \\
\text { widely spread } \\
\text { among filamen- } \\
\text { tous cyanobac- } \\
\text { teria }\end{array}$ & $\begin{array}{l}\text { glycosylated } \\
\text { lipopeptide }\end{array}$ & $\begin{array}{l}\text { A. fumigatus } \\
\text { C. albicans }\end{array}$ & $3.5 \mu \mathrm{M}$ & $\begin{array}{l}\text { activity data of congener A; also ac- } \\
\text { tive against Fusarium, Ustilago, Peni- } \\
\text { cillium; not active against Bacillus } \\
\text { subtilis, Streptomyces versicolor, E. } \\
\text { coli; cytotoxicity } 10 \text {-fold higher }\end{array}$ & $\begin{array}{l}{[136,} \\
137]\end{array}$ \\
\hline Laxaphycins & $\begin{array}{l}\text { Anabaena laxa, } \\
\text { Moorea pro- } \\
\text { ducens, Anabae- } \\
\text { na torulosa }\end{array}$ & cyclic peptides & A. oryzae & $20 \mu \mathrm{M}$ & $\begin{array}{l}\text { also active against } C \text {. albicans, } \\
\text { P. notatum, S. cerevisiae, and } \\
\text { T. mentagrophytes; synergistic } \\
\text { effects between congeners A and B; } \\
\text { cytotoxicity about } 0.2 \mu \mathrm{M}\end{array}$ & $\begin{array}{l}{[141-} \\
144]\end{array}$ \\
\hline $\begin{array}{l}\text { Lobocyclamide } \\
\text { A-D }\end{array}$ & $\begin{array}{l}\text { Lyngbya confer- } \\
\text { voides }\end{array}$ & $\begin{array}{l}\text { cyclic lipopep- } \\
\text { tides }\end{array}$ & C. albicans & $10 \mu \mathrm{M}$ & $\begin{array}{l}\text { MIC of a synergistic mixture of } \\
\text { congeners } A \text { and } B\end{array}$ & {$[163]$} \\
\hline Lyngbyabellin B & $\begin{array}{l}\text { Lyngbya majus- } \\
\text { cula/Moorea pro- } \\
\text { ducens }\end{array}$ & $\begin{array}{l}\text { cyclic depsipep- } \\
\text { tide }\end{array}$ & C. albicans & 10 mm@150 nmol & $\begin{array}{l}\text { also brine shrimp toxicity ( } \mathrm{LD}_{50} \\
\text { of } 4.4 \mu \mathrm{M} \text { ); not active against } \\
\text { P. aeruginosa, E. coli, S. cholerae-suis, } \\
\text { B. subtilis, S. aureus }\end{array}$ & {$[158]$} \\
\hline $\begin{array}{l}\text { Majusculamide } \\
\text { C }\end{array}$ & $\begin{array}{l}\text { Lyngbya majus- } \\
\text { cula/Moorea pro- } \\
\text { ducens }\end{array}$ & $\begin{array}{l}\text { cyclic depsipep- } \\
\text { tide }\end{array}$ & $\begin{array}{l}\text { R. solani } \\
\text { P. aphaniderma- } \\
\text { tum } \\
\text { A. euteiches } \\
\text { P. infestans }\end{array}$ & $\begin{array}{l}4 \mu \mathrm{M} \\
<1 \mu \mathrm{M} \\
2 \mu \mathrm{M} \\
1 \mu \mathrm{M}\end{array}$ & $\begin{array}{l}\mathrm{ED}_{50} \text { values given; also cytotoxic } \\
\left(\mathrm{ED}_{50} / \mathrm{Gl}_{50} \text { at } 20-750 \mathrm{nM}\right)\end{array}$ & $\begin{array}{l}{[146-} \\
148]\end{array}$ \\
\hline Majusculoic acid & Undefined & lipid & C. albicans & $8 \mu \mathrm{M}$ & $\begin{array}{l}\text { cytotoxicity not tested; fluconazole- } \\
\text { resistant Candida strains also resist- } \\
\text { ant against majusculoic acid }\end{array}$ & {$[162]$} \\
\hline $\begin{array}{l}\text { Nostofungici- } \\
\text { dine }\end{array}$ & Nostoc commune & $\begin{array}{l}\text { cyclic lipo- } \\
\text { peptide }\end{array}$ & A. candidus & $1.5 \mu \mathrm{M}$ & $\begin{array}{l}\text { also cytotoxic }\left(\mathrm{IC}_{50} 1.5 \mu \mathrm{M}, \mathrm{NSF}-60\right. \\
\text { cells) }\end{array}$ & [159] \\
\hline $\begin{array}{l}\text { Scytophycins } \\
\text { and Tolytoxins }\end{array}$ & $\begin{array}{l}\text { Scytonema sp. } \\
\text { Tolypothrix sp. }\end{array}$ & macrolides & $\begin{array}{l}\text { S. pastorianus } \\
\text { N. crassa } \\
\text { C. albicans } \\
\text { P. ultimum } \\
\text { R. solani } \\
\text { S. homoeocarpa }\end{array}$ & $\begin{array}{l}24 \mathrm{~mm} @ 1.2 \mu \mathrm{mol} \\
30 \mathrm{~mm} @ 1.2 \mu \mathrm{mol} \\
23 \mathrm{~mm} @ 1.2 \mu \mathrm{mol} \\
>30 \mathrm{~mm} @ 1.2 \mu \mathrm{mol} \\
30 \mathrm{~mm} @ 1.2 \mu \mathrm{mol} \\
>30 \mathrm{~mm} @ 1.2 \mu \mathrm{mol}\end{array}$ & $\begin{array}{l}\text { activity given for scytophycin A; } \\
\text { also cytotoxic }\left(\mathrm{IC}_{50} 50-100 \mathrm{nM}\right)\end{array}$ & $\begin{array}{l}{[149-} \\
154]\end{array}$ \\
\hline Scytoscalarol & Scytonema sp. & sesterterpene & C. albicans & $4 \mu \mathrm{M}$ & $\begin{array}{l}\text { also antibacterial and weakly } \\
\text { cytotoxic (IC } 50135 \mu \mathrm{M})\end{array}$ & [81] \\
\hline Tanikolide & $\begin{array}{l}\text { Lyngbya majus- } \\
\text { cula/Moorea pro- } \\
\text { ducens }\end{array}$ & $\begin{array}{l}\text { fatty acid/ } \\
\delta \text {-lactone }\end{array}$ & C. albicans & 13 mm@350 nmol & $\begin{array}{l}\text { also brine shrimp and snail toxicity } \\
\left(\mathrm{LD}_{50} 12 \mu \mathrm{M} / 32 \mu \mathrm{M}\right)\end{array}$ & $\begin{array}{l}{[156,} \\
157]\end{array}$ \\
\hline Tjipanazoles & $\begin{array}{l}\text { Tolypothrix tjipa- } \\
\text { nasensis } \\
\text { Fischerella ambi- } \\
\text { gua }\end{array}$ & $\begin{array}{l}\text { indolocarba- } \\
\text { zoles }\end{array}$ & $?$ & $?$ & $\begin{array}{l}\text { also weak cytotoxicity; no inhibition } \\
\text { of protein kinase } C \text { at } 1 \mu \mathrm{M}\end{array}$ & {$[164]$} \\
\hline $\begin{array}{l}\text { Tolybyssidins } \\
\text { A/B }\end{array}$ & $\begin{array}{l}\text { Tolypothrix } \\
\text { byssoidea }\end{array}$ & cyclic peptide & C. albicans & 22 and $42 \mu \mathrm{M}$ & cytotoxicity not tested & {$[160]$} \\
\hline
\end{tabular}




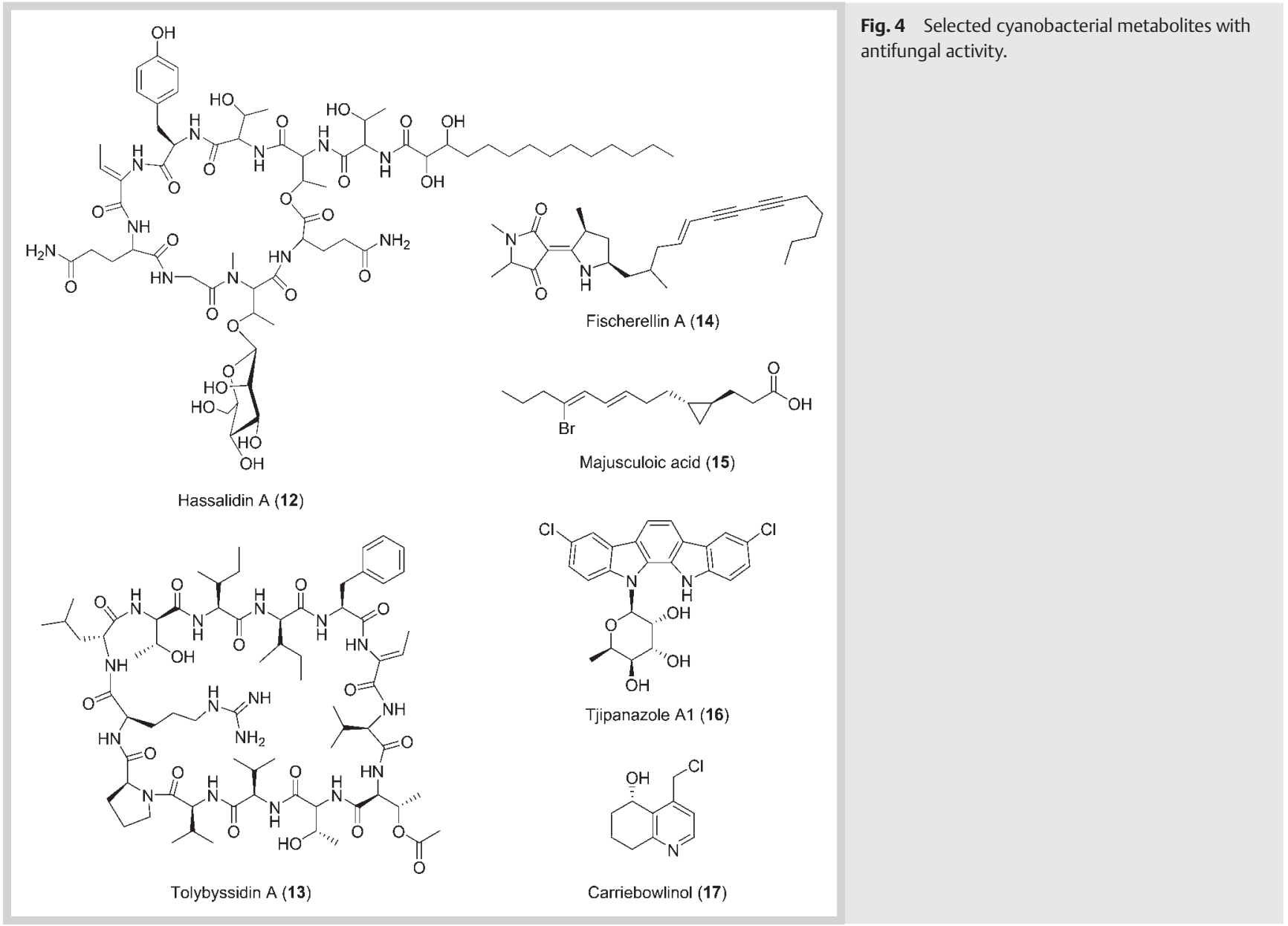

albicans (MIC of $8 \mu \mathrm{M}$ ) [162]. Fluconazole-resistant strains, however, were also resistant against majusculoic acid. Due to its close chemical similarity with lyngbyoic acid (10), it is possible that 15 could also have QS-inhibiting activity.

The lobocyclamides are cyclic lipopeptides from Lyngbya confervoides. A mixture of lobocyclamides A and B had higher activity against a fluconazole-resistant $C$. albicans than the separate compounds (MIC of the mixture $10 \mu \mathrm{M}$ ) [163].

The tjipanazoles (e.g., tjipanazole A1 16) from Tolypothrix tjipanasensis and Fischerella ambigua were found to be active against a range of phytopathogenic fungi, which is in contrast to other indolocarbazoles that show only weak cytotoxicity and no inhibition of protein kinase C [164]. The alkaloid carriebowlinol (17) has recently been isolated from a yet unclassified cyanobacterium. It showed high antifungal activity $\left(\mathrm{IC}_{50}\right.$ of $\left.0.2-0.4 \mu \mathrm{M}\right)$ and activity against marine bacteria [96]. Scytoscalarol (4) has already been discussed due to its antibacterial activity. It also possesses antifungal activity (MIC against $C$. albicans $4 \mu \mathrm{M}$; cytotoxicity $>$ 30-fold lower) [81].

\section{Antiviral Substances}

$\nabla$

A number of screening campaigns have identified cyanobacteria as a potential source for antiviral compounds [165-168]. More detailed studies have been done on sulfoglycolipids and lectins.

\section{Sulfoglycolipids}

Antiviral sulfoglycolipids such as sulfolipid 1 (18, ๑ Fig.5) were isolated from the genera Lyngbya, Phormidium, and Scytonema, and also identified in Anabaena, Calothrix, and Oscillatoria. These compounds as well as structurally related acylated diglycolipids from Oscillatoria and Phormidium show inhibition of the human immunodeficiency virus (HIV-1) via inhibition of the DNA polymerase function of HIV-1 reverse transcriptase [169-171]. Interestingly, the sulfoglycolipids, showing $\mathrm{IC}_{50}$ values as low as $25 \mathrm{nM}$, are an order of magnitude more active than the related glycolipids without the sulfonic acid group [170]. Esterification of the free hydroxyl groups of the sulfosugar with further fatty acids leads to a significant decrease of activity [171]. The presence of the fatty acid chains of the sulfoglycolipids are mandatory for activity. Alterations in the fatty acids (e.g., 16:0, 16:1, 18:1, $18: 2,18: 3)$, however, have a neglectable effect on potency [169, $171]$.

\section{Lectins}

Cyanovirin-N is a peptide lectin isolated from Nostoc ellipsosporum, comprising 101 amino acid residues [172,173]. It targets $\mathrm{N}$-linked, high-mannose glycans [174-176], and was found to be a fusion inhibitor, preventing infection with all HI virus types. Cyanovirin- $\mathrm{N}$ is active in the low nanomolar range and noncytotoxic at a thousandfold higher concentration. It is also strongly active against influenza $A$ and $B$, respiratory syncytial virus, enteric viruses, and several coronaviruses $[177,178]$. As the compound is readily available by heterologous expression in E. coli 


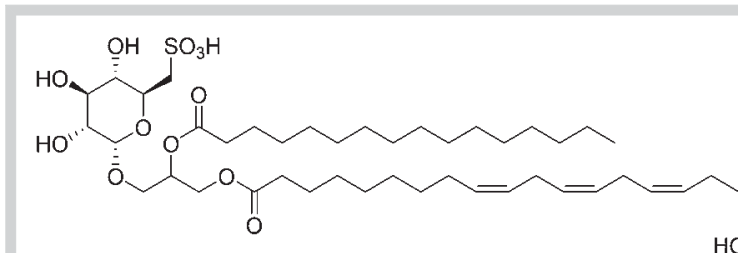

Sulfolipid 1 (18)
Fig. 5 Selected cyanobacterial metabolites with antiviral activity.

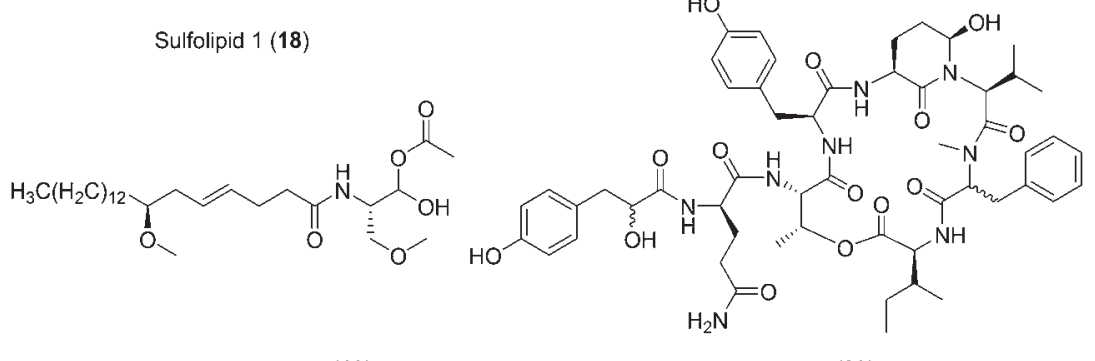

and can also be optimized by rational design [179], it is discussed as a promising template for antiviral lectins. Applications for cyanovirin-N are under current investigation [180], although safety issues such as the release of chemokines and stimulatory/mitogenic activity have been recognized [181]. Recently, microvirin, a lectin with a comparable pharmacophor but supposedly better safety profile, has been isolated from Microcystis aeruginosa [182]. A third antiviral lectin from cyanobacteria with similar properties is scytovirin, isolated from Scytonema varium [183].

\section{Other antiviral compounds}

Nostoflan is a complex acidic polysaccharide from Nostoc flagelliforme [184]. It inhibits the virus-cell interaction of enveloped viruses such as herpes simplex virus, human cytomegalovirus, and influenza A virus, whose cellular receptors are carbohydrates. Interestingly, it exhibits only a very low cytotoxicity and, in contrast to sulfated antiviral polysaccharides, does not show antithrombin activity. Serinol-derived malyngamides (e.g., derivative 19), isolated from an unidentified cyanobacterium, display weak anti-HIV activity [185]. Activity against influenza A virus has been found for the ichthyopeptins $A(20)$ and $B\left(\mathrm{IC}_{50}\right.$ of $\left.12 \mu \mathrm{M}\right)$, isolated from Microcystis ichthyolabe [186]. Other antiviral compounds show significant cytotoxicity. These compounds comprise some aplysiatoxin derivatives from Trichodesmium erythraeum, which are active against Chikungunya virus [187], as well as the $\beta$-carbolines bauerines $\mathrm{A}-\mathrm{C}$ isolated from Dichothrix baueriana [188] and the indolocarbazoles isolated from Nostoc sphaericum [189], both active against herpes simplex virus type 2.

\section{Antiprotozoal Compounds \\ $\nabla$}

Many compounds active against the malaria parasite Plasmodium as well as other protozoal parasites such as Trypanosoma (sleeping sickness or Chagas' disease) or Leishmania (leishmaniasis) have been reported from cyanobacteria [190]. However, as it has already been noted with antibacterial and antifungal compounds, many compounds found to be active in the antiprotozoal assays also display cytotoxicity, limiting their usability as drug leads. It is common to evaluate a compound's selectivity index ( $\mathrm{IC}_{50}$ against human cell lines vs. $\mathrm{IC}_{50}$ against parasites) to assess bioactivity.
The ribosomal cyclic peptide aerucyclamide B (21, \& Fig. $\mathbf{6})$ from $M$. aeruginosa is the most active antiplasmodial compound isolated from cyanobacteria to date [191]. Its IC $_{50}$ of $0.7 \mu \mathrm{M}$ against P. falciparum and an almost 200-fold lower cytotoxicity make it an interesting lead. The structurally closely related balgacyclamides, isolated from a different $M$. aeruginosa strain, show comparable activity [192]. A total synthesis for aerucyclamide B has been established, and the first work on the optimization of the anti-trypanosomal activity of the aerucyclamides has been described, leading to a compound active against $T$. brucei with a selectivity index of about 150 [193].

Synthetic optimization of the linear lipopeptide almiramides from L. majuscula/M. producens has resulted in derivatives (e.g., 22 ) active against Leishmania donovani in the low $\mu \mathrm{M}$ range with selectivity indices of up to $50[194,195]$.

Nostocarbolin has already been discussed in the section "Antibacterial Metabolites". Of special interest concerning antiprotozoal activity is a synthetic nostocarboline dimer (23) that, in addition to having an $\mathrm{IC}_{50}$ of $18 \mathrm{nM}$ against $P$. falciparum, showed a selectivity index against the parasite vs. rat myoblasts of $>2500$. Other dimers were more potent against Trypanosoma or Leishmania [196].

The linear depsipeptide viridamide A (24) from Oscillatoria nigroviridis, structurally distantly related to the almiramides, showed an $\mathrm{IC}_{50}$ in the low $\mu \mathrm{M}$ range against the parasites $P$. falciparum, Trypanosoma cruzi, and Leishmania mexicana. The cytotoxicity data presented do not allow a comparative assessment of cytotoxicity, but activity seems to be in favor of antiparasitic activity [197]. The same holds true for the cyclic depsipeptide companeramides from a yet unclassified filamentous cyanobacterium with moderate antiplasmodial activity [198].

Several compounds with antiprotozoal, but at the same time cytotoxic activities, have been described (selectivity indices $\leq 10$ ). Among these compounds are the lipophilic phenolic ambigols from F. ambigua (already mentioned above) [91] and hierridin B from Phormidium ectocarpi and Cyanobium sp. [199,200], the indolophenanthridine alkaloid calothrixins from Calothrix [201], the linear lipopeptides carmabin A, dragomabin, and dragonamide A [202], the cyclic depsipeptides lagunamide A-C [203, 204] the cyclodepside malyngolide dimer [205] from L. majuscula/M. producens, the cyclic peptides venturamide A and B from Oscillatoria [206], and the linear peptide gallinamide A from 


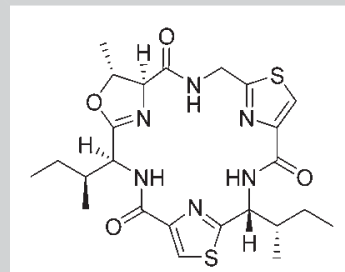

Aerucyclamide B (21)

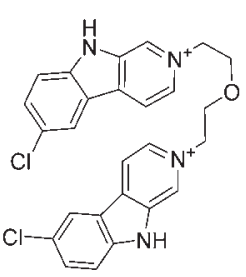

Nostocarboline dimer $(\mathbf{2 3})$<smiles>C#CCCCCC(=O)N(C)[C@@H](C(=O)N(C)C(C(=O)N(C)[C@H](C(=O)N(C)C(C)C(=O)N(C)C(Cc1ccccc1)C(=O)N(C)C)C(C)C)C(C)C)C(C)C</smiles>

Almiramide derivative (22)
Fig. 6 Selected cyanobacterial metabolites with antiprotozoal activity.
Schizothrix [207], which has recently been shown to be a potent inhibitor of human cathepsin L [208].

\section{Molluscicidal Bioactivities \\ $\nabla$}

Schistosomiasis, caused by the parasitic flatworm Schistosoma, is one of the most prevalent parasitic infections worldwide. Hundreds of millions of people are infected and/or at risk of infection, especially in African countries [209,210]. Schistosoma has a complex life cycle that requires both an aquatic snail host belonging to the genus Biomphalaria and a mammalian host to complete their reproductive cycle. As eradicating the disease in infected patients using anthelmintic drugs like praziquantel does not protect against the possibility of reinfection, the treatment of water containing the snail vector with molluscicides like niclosamide is seen as a viable way to protect the population from schistosomiasis. This strategy is widely practiced and nowadays a crucial part of schistosomiasis control, but has several drawbacks such as the price of the applied compounds as well as environmental concerns [211]. Thus, there is a demand for novel molluscicides. As cyanobacteria might produce molluscicidal compounds to protect themselves against snails feeding on cyanobacterial biomass, strains have been screened for molluscicidal activity, and subsequently, several compounds with this bioactivity have been found. Their structures are shown in 8 Fig. 7.

The first compound for which molluscicidal activity has been found is barbamide (25) from L. majuscula/M. producens [212]. It has specific molluscicidal activity ( $\mathrm{LC}_{100}$ of $\left.21.6 \mu \mathrm{M}\right)$, and does not show brine shrimp toxicity or ichthyotoxicity. Due to several intriguing chemical features, like a trichlormethyl group and a methyl enol ether of a $\beta$-keto amide, its biosynthesis has been studied in great detail [213-217].

Cyanolide A (26) from Lyngbya bouillonii is an unusual symmetric glycosidic macrolide. It is more active against Biomphalaria than barbamide ( $\mathrm{LC}_{50}$ of $1.2 \mu \mathrm{M}$ ), but in addition it also shows brine shrimp toxicity ( $\mathrm{LC}_{50}$ of $10.8 \mu \mathrm{M}$ ) [218]. As the compounds cytotoxicity is comparably low (nontoxic at $35 \mu \mathrm{M}$ ), its total synthesis has received considerable attention (e.g., [219-222]).

Thiopalmyrone (27) and palmyrrolinone (28) have been isolated from the same marine cyanobacteria assemblage of Oscillatoria and Hormoscilla. Both compounds activities were in the low micromolar range ( $\mathrm{LC}_{50} \mathrm{~s}$ of 8.3 and $6.0 \mu \mathrm{M}$, resp.) [223]. As the compounds were not antifungal, antibacterial, or cytotoxic up to a concentration of $100 \mu \mathrm{M}$, they seem to be selectively molluscicidal and deserve closer attention.

\section{Conclusions}

$\nabla$

To date, many compounds with anti-infective activities have been isolated from cyanobacteria. Most of the isolated compounds showed cytotoxicity in addition to the desired anti-infective activity, limiting their direct use as anti-infective drug substances. However, they might well serve as lead compounds for the development of derivatives with a lower toxicity, a common approach in pharmaceutical natural product chemistry.

Interestingly, despite intense screening campaigns searching for novel antibacterial compounds from cyanobacteria, these organisms have only been a poor source for selective antibacterial compounds, in contrast to other microorganisms such as the soil dwelling actinomycetes (of the about 7000 known compounds from the genus Streptomyces, about 2600 compounds have antibiotic activity) or microscopic fungi. An explanation for this observation might be the unique lifestyle of cyanobacteria compared with the aforementioned microorganisms. Photosynthetic cyanobacteria as autotrophs and primary producers serve as food for a plethora of micro- and macroorganisms [224]. They do not directly compete with heterotrophic bacteria for organic nutrients in their environment, but rather compete with other phototrophic organisms or eukaryotic organisms grazing on cyanobacteria. That might explain why the synthesis of antibacterial compounds might only be of limited evolutionary advantage, while the production of compounds with toxicity against other phototrophic organisms or eukaryotic organisms might be favored. This could suggest that searching for cyanobacterial compounds targeting eukaryotes such as fungi, protozoa, and mollusks might be more fruitful than searching for antibacterial metabolites in cyanobacteria. But, as has been noted above, cyanobacteria are still poorly researched. Thus, it can be expected that selective antibacterials will also be found in these organisms sooner or later. Another interesting aspect to note concerning the compounds found to have antibacterial activity is that they most often are not peptides, the structural class most often ob- 


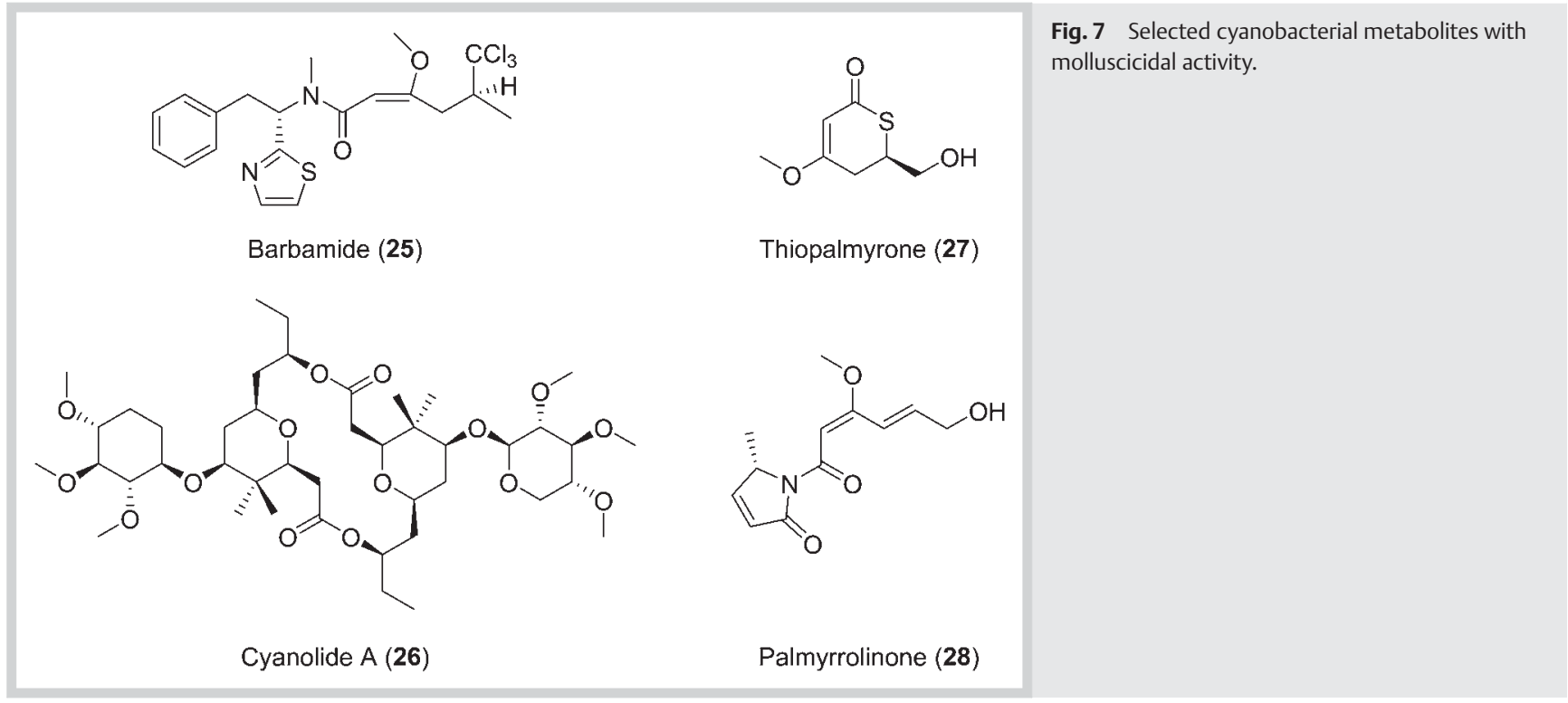

served in cyanobacteria. Instead, mainly polyketides, terpenes, and alkaloids have been found to exert antibacterial activity. This might be due to the fact that peptides have physicochemical properties unsuitable for crossing cell walls. It is also worth mentioning that cyanobacterial secondary metabolites have more often been isolated from the biomass rather than from the cultivation medium. For example, amongst the antibacterial compounds summarized in this review, only bromoanaindolone, the comnostins, and noscomin have been described as being isolated from the cultivation medium. Although this finding is slightly biased due to the fact that cyanobacteria biomass has simply been better studied in the past compared to cyanobacteria cultivation media, it might indicate that the antibacterial compounds found to date have not evolved to act as antibacterials, as this would need export or diffusion into the extracellular environment. It might be sensible to intensify the examination of compounds secreted into the medium during cyanobacteria cultivation for the purpose of finding novel anti-infective secondary metabolites from these organisms.

A rather novel field is the search for cyanobacterial QS inhibitors as indirect antibacterials. Own screening results (not discussed here) confirm that cyanobacteria have a good potential in this area, and the isolation of QS-inhibiting natural compounds from hit extracts is under way in our laboratory. Antiviral lectins are the most advanced anti-infective compounds from cyanobacteria, although no compound has reached the market, yet.

Not discussed within the scope of this review is the potential of cyanobacterial protease inhibitors as anti-infective compounds. As many potent protease inhibitors have been isolated from cyanobacteria [22], and proteases are validated or currently discussed targets for treating viral or protozoal infections [225], it can be expected that cyanobacterial compounds will, in the future, play a role in this research field.

As discussed above, the pace of cyanobacterial natural product research has increased. We expect that the majority of cyanobacterial genera, species, and strains have not even been discovered yet, and that novel cyanobacterial metabolites with interesting bioactivities will continuously be described as more academic and industrial groups acknowledge the potential of their exploitation. In view of the relatively small overall number of cyanobac- terial strains and isolated secondary metabolites investigated, it is remarkable that several of them have already entered clinical trials, and that one analog based on the dolastatins could successfully be developed into a marketed drug (brentuximab vedotin). A more thorough exploitation of cyanobacterial natural products for drug discovery will potentially increase the number of successful drug discoveries in the future, also in the field of anti-infective drugs.

Often, the suitability of cyanobacteria as producers of secondary metabolites is controversially discussed. However, great advances have been made in this field. Cyanobacteria as photosynthetic autotrophs do not require carbon or energy sources supplied in the cultivation media, but accept cultivation in inorganic salt solutions. This facilitates medium standardization and logistics when mass cultivations are needed. The downstream processing (the isolation of the secondary metabolites) is straightforward, as the products do not have to be separated from a complex organic medium. Furthermore, the use of inorganic medium ingredients reduces the costs and hampers the growth of contaminating heterotrophic organisms. However, cultivation facilities with artificial or natural illumination and photobioreactor systems have yet to be established before cyanobacteria can be utilized to produce active pharmaceutical ingredients (APIs) under GMP-compliant conditions.

The longer generation times compared to, e.g., E. coli (about 1 day vs. about $20 \mathrm{~min}$ ), result in substantially longer cultivation times to reach a given amount of biomass. Also, production titers of secondary metabolites are still 2-3 orders of magnitude lower compared to the optimized industrial bacterial or fungal production systems. These considerations have led to several developments. Firstly, most programs that pursue leads from cyanobacteria make a switch from cyanobacteria cultivation/processing to total synthesis in order to produce multigram quantities of a drug substance. Secondly, research on the production of cyanobacterial secondary metabolites in heterologous hosts such as E. coli has been taken up. The proof-of-principle that complex ribosomal metabolites and more simple cyanobacterial metabolites can be produced in this way has successfully been brought forward [226-230]. However, due to the size and multifunctional character of PKS/NRPS biosynthesis complexes, the heterologous ex- 
pression of non-ribosomal cyanobacterial peptides is a significant challenge, and no successful example has been published to date. A third possibility to overcome the lower relative productivity is the development of low-cost large-scale photobioreactors allowing for cost efficient mass cultivation of the cyanobacteria of interest. In this context, the significant progress made in regard to using microalgae for food as well as biofuels and chemical feedstock production will also support the development of novel low-cost photobioreactors for high-value products, such as pharmaceuticals.

Therefore, we advocate striving for intensified drug discovery efforts from cyanobacteria as well as for improved biotechnological and process engineering solutions for compound production.

\section{Acknowledgement}

$\nabla$

I thank M. Preisitsch, University of Greifswald, Germany, and Dr. D. Kramer, Cyano Biotech GmbH, Berlin, Germany, for helpful discussions and critically reading the manuscript. Parts of this review have been published before in reference [22].

\section{Conflict of Interest}

$\nabla$

The author has been employee at the company Cyano Biotech GmbH, Berlin, Germany, until 11/2013. He still serves in the academic advisory board of the company.

\section{References}

1 Hayes GW, Keating CL, Newman JS. The golden anniversary of the silver bullet. JAMA 1993; 270: 1610-1611

2 Kardos N, Demain AL. Penicillin: the medicine with the greatest impact on therapeutic outcomes. Appl Microbiol Biotechnol 2011; 92: 677687

3 Newman DJ, Cragg GM. Natural products as sources of new drugs over the 30 years from 1981 to 2010. J Nat Prod 2012; 75: 311-335

4 Cooper MA, Shlaes D. Fix the antibiotics pipeline. Nature 2011; 472: 32

5 Boucher HW, Talbot GH, Bradley JS, Edwards JE, Gilbert D, Rice LB, Scheld $M$, Spellberg B, Bartlett J. Bad bugs, no drugs: no ESKAPE! An update from the Infectious Diseases Society of America. Clin Infect Dis 2009; 48: $1-12$

6 Freire-Moran L, Aronsson B, Manz C, Gyssens IC, So AD, Monnet DL, Cars 0 ; ECDC-EMA Working Group. Critical shortage of new antibiotics in development against multidrug-resistant bacteria-Time to react is now. Drug Resist Updat 2011; 14: 118-124

7 ECDC/EMEA. ECDC/EMEA Joint Technical Report. The bacterial challenge: time to react. Stockholm: ECDC/EMEA; 2009

8 The White House. National strategy for combating antibiotic-resistant bacteria. Washington: The White House; 2014

9 World Health Organization. Antimicrobial resistance: global report on surveillance. Geneva: World Health Organization; 2014

10 Butler MS. The role of natural product chemistry in drug discovery. J Nat Prod 2004; 67: 2141-2153

11 Harvey $A$. Natural products in drug discovery. Drug Discov Today 2008; 13: 894-901

12 Newman DJ. Natural products as leads to potential drugs: an old process or the new hope for drug discovery? J Med Chem 2008; 51 : $2589-2599$

13 van Apeldoorn ME, van Egmond HP, Speijers GJA, Bakker GJI. Toxins of cyanobacteria. Mol Nutr Food Res 2007; 51: 7-60

14 Pegram RA, Humpage AR, Neilan BA, Runnegar MT, Nichols T, Thacker RW, Pflugmacher S, Etherodge SM, Love AH. Cyanotoxins Workgroup report. Adv Exp Med Biol 2008; 619: 317-381

15 Pearson L, Mihali T, Moffitt M, Kellmann R, Neilan B. On the chemistry, toxicology and genetics of the cyanobacterial toxins, microcystin, nodularin, saxitoxin and cylindrospermopsin. Mar Drugs 2010; 8: 16501680
16 Burja AM, Banaigs B, Abou-Mansour E, Burgess JG, Wright PC. Marine cyanobacteria - a prolific source of natural products. Tetrahedron 2001; 57: 9347-9377

17 Tan LT. Bioactive natural products from marine cyanobacteria for drug discovery. Phytochemistry 2007; 68: 954-979

18 Gademann K. Out in the green: biologically active metabolites produced by cyanobacteria. Chimia 2011; 65: 416-419

19 Gademann K, Portmann C. Secondary Metabolites from Cyanobacteria: Complex Structures and Powerful Bioactivities. Curr Org Chem 2008; 12: $326-341$

20 Tan LT. Filamentous tropical marine cyanobacteria: a rich source of natural products for anticancer drug discovery. J Appl Phycol 2010; 22: 659-676

21 Tidgewell K, Clark BR, Gerwick WH. The natural products chemistry of cyanobacteria. In: Mander L, Liu HW, editors. Comprehensive natural products II: chemistry and biology. Oxford: Elsevier; 2010: 141-188

22 Niedermeyer T, Brönstrup M. Natural-product drug discovery from microalgae. In: Posten C, Walter C, editors. Microalgal biotechnology: integration and economy. Berlin, Boston: de Gruyter; 2012: 169-200

23 Salvador-Reyes LA, Luesch $\mathrm{H}$. Biological targets and mechanisms of action of natural products from marine cyanobacteria. Nat Prod Rep 2015; 32: 478-503

24 Jaspars M, Lawton LA. Cyanobacteria - a novel source of pharmaceuticals. Curr Opin Drug Discov Devel 1998; 1: 77-84

25 Dictionary of Natural Products on DVD. London: Taylor \& Francis Group; 2013

26 Schopf JW, Packer BM. Early Archean (3.3-billion to 3.5-billion-yearold) microfossils from Warrawoona Group, Australia. Science 1987; 237: 70-73

27 Whitton BA, Potts $M$. The ecology of cyanobacteria: their diversity in time and space. Dordrecht: Springer; 2000

28 Nagle DG, Paul VJ. Production of secondary metabolites by filamentous tropical marine cyanobacteria: ecological functions of the compounds. J Phycol 1999; 35: 1412-1421

29 Berry JP, Gantar M, Perez MH, Berry G, Noriega FG. Cyanobacterial toxins as allelochemicals with potential applications as algaecides, herbicides and insecticides. Mar Drugs 2008; 6: 117-146

30 Trimurtulu G, Ohtani I, Patterson GML, Moore RE, Corbett TH, Valeriote FA, Demchik L. Total Structures of Cryptophycins, Potent Antitumor Depsipeptides from the Blue-Green Alga Nostoc sp. Strain GSV 224. J Am Chem Soc 1994; 116: 4729-4737

31 Panda D, Himes RH, Moore RE, Wilson L, Jordan MA. Mechanism of action of the unusually potent microtubule inhibitor cryptophycin 1 . Biochemistry 1997; 36: 12948-12953

32 Rohr J. Cryptophycin anticancer drugs revisited. ACS Chem Biol 2006; 1: 747-750

33 Pettit GR, Kamano Y, Herald CL, Tuinman AA, Boettner FE, Kizu $H$, Schmidt JM, Baczynskyi L, Tomer KB, Bontemps RJ. The isolation and structure of a remarkable marine animal antineoplastic constituent: dolastatin 10. J Am Chem Soc 1987; 109: 6883-6885

34 Flahive E, Srirangam J. The dolastatins: novel antitumor agents from Dolabella auricularia. In: Kingston D, Cragg G, Newman D, editors. Anticancer agents from natural products. Boca Raton: CRC Press; 2005: 191-214

35 Guyot M, Doré JC, Devillers J. Typology of secondary cyanobacterial metabolites from minimum spanning tree analysis. SAR QSAR Environ Res 2004; 15: 101-114

36 Welker M, von Döhren H. Cyanobacterial peptides - nature's own combinatorial biosynthesis. FEMS Microbiol Rev 2006; 30: 530-563

37 Jones AC, Monroe EA, Eisman EB, Gerwick L, Sherman H, Gerwick WH. The unique mechanistic transformations involved in the biosynthesis of modular natural products from marine cyanobacteria. Nat Prod Rep 2010; 27: 1048-1065

38 Dittmann E, Neilan BA, Börner T. Molecular biology of peptide and polyketide biosynthesis in cyanobacteria. Appl Microbiol Biotechnol 2001; 57: 467-473

39 Schwarzer D, Finking R, Marahiel MA. Nonribosomal peptides: from genes to products. Nat Prod Rep 2003; 20: 275-287

40 Challis GL, Naismith JH. Structural aspects of non-ribosomal peptide biosynthesis. Curr Opin Struct Biol 2004; 14: 748-756

41 Finking R, Marahiel MA. Biosynthesis of nonribosomal peptides. Annu Rev Microbiol 2004; 58: 453-488

42 Barrios-llerena ME, Burja AM, Wright PC. Genetic analysis of polyketide synthase and peptide synthetase genes in cyanobacteria as a mining 
tool for secondary metabolites. J Ind Microbiol Biotechnol 2007; 34: 443-456

43 Jones AC, Gu L, Sorrels CM, Sherman DH, Gerwick WH. New tricks from ancient algae: natural products biosynthesis in marine cyanobacteria. Curr Opin Chem Biol 2009; 13: 216-223

44 Kalaitzis JA, Lauro FM, Neilan BA. Mining cyanobacterial genomes for genes encoding complex biosynthetic pathways. Nat Prod Rep 2009; 26: 1447-1465

45 Marahiel MA. Working outside the protein-synthesis rules: insights into non-ribosomal peptide synthesis. J Pept Sci 2009; 15: 799-807

46 Rath CM, Scaglione JB, Kittendorf JD, Sherman DH. NRPS/PKS hybrid enzymes and their natural products. In: Mander L, Liu HW, editors. Comprehensive natural products II: chemistry and biology. Oxford: Elsevier: 2010: 453-492

47 Strieker M, Tanović A, Marahiel MA. Nonribosomal peptide synthetases: structures and dynamics. Curr Opin Struct Biol 2010; 20: 234 240

48 Ziemert N, Ishida K, Liaimer A, Hertweck C, Dittmann E. Ribosomal synthesis of tricyclic depsipeptides in bloom-forming cyanobacteria. Angew Chem Int Ed Engl 2008; 47: 7756-7759

49 Donia MS, Schmidt EW. Cyanobactins - ubiquitous cyanobacterial ribosomal peptide metabolites. In: Mander L, Liu HW, editors. comprehensive natural products II: chemistry and biology. Oxford: Elsevier; 2010: 14-17

50 Sivonen K, Leikoski N, Fewer DP, Jokela J. Cyanobactins - ribosomal cyclic peptides produced by cyanobacteria. Appl Microbiol Biotechnol 2010; 86: 1213-1225

51 Hershberger SJ, Lee SG, Chmielewski J. Scaffolds for blocking proteinprotein interactions. Curr Top Med Chem 2007; 7: 928-942

52 Driggers EM, Hale SP, Lee J, Terrett NK. The exploration of macrocycles for drug discovery-an underexploited structural class. Nat Rev Drug Discov 2008; 7: 608-624

53 Gerwick WH, Coates RC, Engene N, Gerwick L, Grindberg RV, Jones AC, Sorrels CM. Giant marine cyanobacteria produce exciting potential pharmaceuticals. Microbe 2008; 3: 277-284

54 Engene N, Rottacker EC, Kaštovský J, Byrum T, Choi H, Ellisman MH, Komárek J, Gerwick WH. Moorea producens gen. nov., sp. nov. and Moorea bouillonii comb. nov., tropical marine cyanobacteria rich in bioactive secondary metabolites. Int J Syst Evol Microbiol 2012; 62: 1171-1178

55 Shimizu Y. Microalgal metabolites. Curr Opin Microbiol 2003; 6: 236243

56 Liu L, Rein KS. New peptides isolated from Lyngbya species: a review. Mar Drugs 2010; 8: 1817-1837

57 Niedermeyer THJ. Microcystin congeners described in the literature. December 19, 2013; DOI: 10.6084/m9.figshare.880756

58 Kehr JC, Picchi DG, Dittmann E. Natural product biosyntheses in cyanobacteria: A treasure trove of unique enzymes. Beilstein J Org Chem 2011; $7:$ 1622-1635

59 Sielaff H, Christiansen G, Schwecke T. Natural products from cyanobacteria: Exploiting a new source for drug discovery. IDrugs 2006; 9: 119127

60 Zhang W, Tang Y. Combinatorial biosynthesis of natural products. J Med Chem 2008; 51: 2629-2633

61 Meeks JC, Elhai J, Thiel T, Potts M, Larimer F, Lamerdin J, Predki P, Atlas R. An overview of the genome of Nostoc punctiforme, a multicellular, symbiotic cyanobacterium. Photosynth Res 2001; 70: 85-106

62 Cragg GM, Grothaus PG, Newman DJ. Impact of natural products on developing new anti-cancer agents. Chem Rev 2009; 109: 3012-3043

63 Olaizola M. Commercial development of microalgal biotechnology: from the test tube to the marketplace. Biomol Eng 2003; 20: 459-466

64 Cardllina JH 2nd, Moore RE, Arnold EV, Clardy J. Structure and absolute configuration of malyngolide, an antibiotic from the marine bluegreen alga Lyngbya majuscula Gomont. J Org Chem 1979; 44: 40394042

65 Kozikowski AP, Nieduzak TR, Scripko J. Hydroxymercuration-reductive coupling route to delta-lactones. Synthesis of malyngollde, an antibiotic from a marine blue-green alga. Organometallics 1982; 1: 675-676

66 Cardillo G, Orena M, Porzi G, Sandri S. Synthesis of malyngolide, an antibiotic from the marine blue-green alga Lyngbya majuscula Gomont. J Org Chem 1981; 46: 2439-2442

67 Sakito Y, Tanaka S, Asami M, Mukiyama T. An asymmetric total synthesis of a new marine antibiotic-malyngolide. Chem Lett 1980; 9: 12231226
68 Moore RE, Cheuk C, Patterson GML. Hapalindoles: new alkaloids from the blue-green alga Hapalosiphon fontinalis. J Am Chem Soc 1984; 106: 6456-6457

69 Moore RE, Cheuk C, Yang XQG, Patterson GML, Bonjouklian R, Smitka TA, Mynderse JS, Foster RS, Jones ND, Swartzendruber JK, Deeter JB. Hapalindoles, antibacterial and antimycotic alkaloids from the cyanophyte $\mathrm{Ha}$ palosiphon fontinalis. J Org Chem 1987; 52: 1036-1043

70 Klein D, Daloze D, Braekman JC, Hoffmann L, Demoulin V. New apalindoles from the cyanophyte Hapalosiphon laingii. J Nat Prod 1995; 58: 1781-1785

71 Asthana RK, Srivastava A, Singh AP, Singh SP, Nath G, Srivastava R, Srivastava $B S$. Identification of an antimicrobial entity from the cyanobacterium Fischerella sp. isolated from bark of Azadirachta indica (Neem) tree. J Appl Phycol 2006; 18: 33-39

72 Kim H, Lantvit D, Hwang CH, Kroll DJ, Swanson SM, Franzblau SG, Orjala J. Indole alkaloids from two cultured cyanobacteria, Westiellopsis sp. and Fischerella muscicola. Bioorg Med Chem 2012; 20: 5290-5295

73 Bonjouklian R, Moore RE, Mynderse JS, Patterson GML, Smitka TA. Hapalindoles. US Patent 4870185; 1989

74 Becher PG, Keller S, Jung G, Süssmuth RD, Jüttner F. Insecticidal activity of 12-epi-hapalindole J isonitrile. Phytochemistry 2007; 68: 2493-2497

75 Cagide E, Becher PG, Louzao MC, Espiña B, Vieytes MR, Jüttner F, Botana $L M$. Hapalindoles from the cyanobacterium fischerella: potential sodium channel modulators. Chem Res Toxicol 2014; 27: 1696-1706

76 Raveh A, Carmeli S. Antimicrobial ambiguines from the cyanobacterium Fischerella sp. collected in Israel. J Nat Prod 2007; 70: 196-201

77 Mo S, Krunic A, Chlipala G, Orjala J. Antimicrobial ambiguine isonitriles from the cyanobacterium Fischerella ambigua. J Nat Prod 2009; 72: 894-899

78 Jaki B, Orjala J, Sticher O. A novel extracellular diterpenoid with antibacterial activity from the cyanobacterium Nostoc commune. J Nat Prod 1999; 62: 502-503

79 Jaki B, Heilmann J, Sticher 0 . New antibacterial netabolites from the cyanobacterium Nostoc communem (EAWAG 122b). J Nat Prod 2000; 63 1283-1285

80 Jaki B, Orjala J, Heilmann J, Linden A, Vogler B, Sticher O. Novel extracellular diterpenoids with biological activity from the cyanobacterium Nostoc commune. J Nat Prod 2000; 63: 339-343

81 Mo S, Krunic A, Pegan SD, Franzblau SG, Orjala J. An antimicrobial guanidine-bearing sesterterpene from the cultured cyanobacterium Scytonema sp. J Nat Prod 2009; 72: 2043-2045

82 Espinoza-Moraga M, Njuguna NM, Mugumbate G, Caballero J, Chibale K. In silico comparison of antimycobacterial natural products with known antituberculosis drugs. J Chem Inf Model 2013; 53: 649-660

83 Sturdy M, Krunic A, Cho S, Franzblau S, Orjala J. Eucapsitrione, an antiMycobacterium tuberculosis anthraquinone derivative from the cultured freshwater cyanobacterium Eucapsis sp. J Nat Prod 2010; 73: 1441-1443

84 Becher PG, Beuchat J, Gademann K, Jüttner F. Nostocarboline: isolation and synthesis of a new cholinesterase inhibitor from Nostoc 78-12A. J Nat Prod 2005; 68: 1793-1795

85 Blom JF, Brütsch T, Barbaras D, Bethuel Y, Locher HH, Hubschwerlen C, Gademann K. Potent algicides based on the cyanobacterial alkaloid nostocarboline. Org Lett 2006; 8: 737-740

86 Bonazzi S, Barbaras D, Patiny L, Scopelliti R, Schneider P, Cole ST, Kaiser M, Brun R, Gademann K. Antimalarial and antitubercular nostocarboline and eudistomin derivatives: synthesis, in vitro and in vivo biological evaluation. Bioorg Med Chem 2010; 18: 1464-1476

87 Locher HH, Ritz D, Pfaff P, Gaertner M, Knezevic A, Sabato D, Schroeder S, Barbaras D, Gademann K. Dimers of nostocarboline with potent antibacterial activity. Chemotherapy 2010; 56: 318-324

88 Raveh A, Carmeli S. Aeruginazole A, a novel thiazole-containing cyclopeptide from the cyanobacterium Microcystis sp. Org Lett 2010; 12: 3536-3539

89 Bruno P, Pena S, Just-Baringo X, Albericio F, Alvarez M. Total synthesis of aeruginazole A. Org Lett 2011; 13: 4648-4651

90 Falch BS, Konig GM, Wright AD, Sticher O, Rüegger H, Bernardinelli G. Ambigol A and B: new biologically active polychlorinated aromatic compounds from the terrestrial blue-green alga Fischerella ambigua. J Org Chem 1993; 58: 6570-6575

91 Wright AD, Papendorf O, König GM. Ambigol C and 2, 4-dichlorobenzoic acid, natural products produced by the terrestrial cyanobacterium $\mathrm{Fi}$ scherella ambigua. J Nat Prod 2005; 68: 459-461 
92 Volk RB, Girreser U, Al-Refai M, Laatsch H. Bromoanaindolone, a novel antimicrobial exometabolite from the cyanobacterium Anabaena constricta. Nat Prod Res 2009; 23: 607-612

93 Bui HTN, Jansen R, Pham HTL, Mundt S. Carbamidocyclophanes A-E, chlorinated paracyclophanes with cytotoxic and antibiotic activity from the Vietnamese cyanobacterium Nostoc sp. J Nat Prod 2007; 70: 499-503

94 Luo S, Kang HS, Krunic A, Chlipala GE, Cai G, Chen WL, Franzblau SG, Swanson SM, Orjala J. Carbamidocyclophanes F and G with anti-Mycobacterium tuberculosis activity from the cultured freshwater cyanobacterium Nostoc sp. Tetrahedron Lett 2014; 55: 686-689

95 Preisitsch M, Harmrolfs K, Pham HT, Heiden SE, Füssel A, Wiesner C, Pretsch A, Swiatecka-Hagenbruch M, Niedermeyer THJ, Müller R, Mundt $S$. Anti-MRSA-acting carbamidocyclophanes $\mathrm{H}-\mathrm{L}$ from the Vietnamese cyanobacterium Nostoc sp. CAVN2. J Antibiot 2014; 68: 165-177

96 Soares AR, Engene N, Gunasekera SP, Sneed JM, Paul VJ. Carriebowlinol, an antimicrobial tetrahydroquinolinol from an assemblage of marine cyanobacteria containing a novel taxon. J Nat Prod 2015; 78: 534-538

97 Jaki B, Orjala J, Sticher O. A novel extracellular diterpenoid with antibacterial activity from the cyanobacterium Nostoc commune. J Nat Prod 1999; 62: 502-503

98 Choi H, Engene N, Smith JE, Preskitt LB, Gerwick WH. Crossbyanols A-D, toxic brominated polyphenyl ethers from the Hawai'ian bloom-forming Cyanobacterium Leptolyngbya crossbyana. J Nat Prod 2010; 73: 517-522

99 Mundt S, Kreitlow S, Jansen $R$. Fatty acids with antibacterial activity from the cyanobacterium Oscillatoria redekei HUB 051. J Appl Phycol 2003; 15: 263-267

100 Doan NT, Rickards RW, Rothschild JM, Smith GD, Thanh Doan N. Allelopathic actions of the alkaloid 12-epi-hapalindole $\mathrm{E}$ isonitrile and calothrixin A from cyanobacteria of the genera Fischerella and Calothrix. J Appl Phycol 2000; 12: 409-416

101 Etchegaray A, Rabello E, Dieckmann R, Moon DH, Fiore MF, von Döhren $H$, Tsai SM, Neilan BA. Algicide production by the filamentous cyanobacterium Fischerella sp. CENA 19. J Appl Phycol 2004; 16: 237-243

102 Ishida K, Matsuda H, Murakami M, Yamaguchi K. Kawaguchipeptin B, an antibacterial cyclic undecapeptide from the cyanobacterium $\mathrm{Mi}$ crocystis aeruginosa. J Nat Prod 1997; 60: 724-726

103 Zainuddin EN, Jansen R, Nimtz M, Wray V, Preisitsch M, Lalk M, Mundt $S$. Lyngbyazothrins A-D, antimicrobial cyclic undecapeptides from the cultured Cyanobacterium lyngbya sp. J Nat Prod 2009; 72: 1373-1378

104 Zi J, Lantvit DD, Swanson SM, Orjala J. Lyngbyaureidamides A and B, two anabaenopeptins from the cultured freshwater cyanobacterium Lyngbya sp. (SAG 36.91). Phytochemistry 2012; 74: 173-177

105 Leão PN, Pereira AR, Liu WT, Ng J, Pevzner PA, Dorrestein PC, König GM, Vasconvelos VM, Gerwick WH. Synergistic allelochemicals from a freshwater cyanobacterium. Proc Natl Acad Sci U S A 2010; 107: $11183-11188$

106 Gerwick WH, Reyes S, Alvarado B. Two malyngamides from the caribbean cyanobacterium Lyngbya majuscula. Phytochemistry 1987; 26: 1701-1704

107 Gunasekera SP, Owle CS, Montaser R, Luesch H, Paul VJ. Malyngamide 3 and cocosamides A and B from the marine cyanobacterium Lyngbya majuscula from Cocos Lagoon, Guam. J Nat Prod 2011; 74: 871-876

108 Thacker RW, Nagle DG, Paul VJ. Effects of repeated exposures to marine cyanobacterial secondary metabolites on feeding by juvenile rabbitfish and parrotfish. Mar Ecol Prog Ser 1997; 147: 21-29

109 Nagatsu A, Kajitani H, Sakakibara J. Muscoride A: A new oxazole peptide alkaloid from freshwater cyanobacterium Nostoc muscorum. Tetrahedron Lett 1995; 36: 4097-4100

110 Wipf P, Venkatraman S. Total Synthesis of (-)-Muscoride A. J Org Chem 1996; 61: 6517-6522

111 Pérez Gutiérrez RM, Martinéz Flores A, Vargas Solís R, Carmona Jiminez $J$. Two new antibacterial norabietane diterpenoids from cyanobacteria, Microcoleous lacustris. J Nat Med 2008; 62: 328-331

112 Ploutno A, Carmeli S. Nostocyclyne A, a novel antimicrobial cyclophane from the cyanobacterium Nostoc sp. J Nat Prod 2000; 63: 1524-1526

113 Luesch H, Pangilinan R, Yoshida WY, Moore RE, Paul VJ. Pitipeptolides A and $B$, new cyclodepsipeptides from the marine cyanobacterium Lyngbya majuscula. J Nat Prod 2001; 64: 304-307

114 Cruz-Rivera E, Paul VJ. Chemical deterrence of a cyanobacterial metabolite against generalized and specialized grazers. J Chem Ecol 2007; 33: 213-217
115 Montaser R, Paul VJ, Luesch H. Pitipeptolides C-F, antimycobacterial cyclodepsipeptides from the marine cyanobacterium Lyngbya majuscula from Guam. Phytochemistry 2011; 72: 2068-2074

116 Pergament I, Carmeli S. Schizotrin A; a novel antimicrobial cyclic peptide from a cyanobacterium. Tetrahedron Lett 1994; 35: 8473-8476

117 Noaman NH, Fattah A, Khaleafa M, Zaky SH. Factors affecting antimicrobial activity of Synechococcus leopoliensis. Microbiol Res 2004; 159: 395-402

118 Martins RF, Ramos MF, Herfindal L, Sousa JA, Skaerven K, Vasconcelos $V M$. Antimicrobial and cytotoxic assessment of marine cyanobacteria - Synechocystis and Synechococcus. Mar Drugs 2008; 6: 1-11

119 Chlipala G, Mo S, Carcache de Blanco EJ, Ito A, Bazarek S, Orjala J. Investigation of antimicrobial and protease-inhibitory activity from cultured cyanobacteria. Pharm Biol 2009; 47: 53-60

120 Silva-Stenico ME, Silva CSP, Lorenzi AS, Shishido TK, Etchegaray A, Lira $S P$, Moraes LAB, Fiore MF. Non-ribosomal peptides produced by Brazilian cyanobacterial isolates with antimicrobial activity. Microbiol Res 2011; 166: 161-175

121 Guedes AC, Barbosa CR, Amaro HM, Pereira CI, Malcata FX. Microalgal and cyanobacterial cell extracts for use as natural antibacterial additives against food pathogens. Int J Food Sci Technol 2011; 46: 862870

122 Waters CM, Bassler BL. Quorum sensing: cell-to-cell communication in bacteria. Annu Rev Cell Dev Biol 2005; 21: 319-346

123 Williams P, Winzer K, Chan WC, Cámara M. Look who's talking: communication and quorum sensing in the bacterial world. Philos Trans R Soc Lond B Biol Sci 2007; 362: 1119-1134

124 Keller L, Surette MG. Communication in bacteria: an ecological and evolutionary perspective. Nat Rev Microbiol 2006; 4: 249-258

125 Schuster M, Joseph Sexton D, Diggle SP, Peter Greenberg E. Acyl-homoserine lactone quorum sensing: from evolution to application. Annu Rev Microbiol 2013; 67: 43-63

126 Defoirdt T, Boon N, Bossier P. Can bacteria evolve resistance to quorum sensing disruption? PLoS Pathog 2010; 6: e1000989

127 Kaufmann GF, Park J, Janda KD. Bacterial quorum sensing: a new target for anti-infective immunotherapy. Expert Opin Biol Ther 2008; 8: 719-724

128 Hirakawa $H$, Tomita $H$. Interference of bacterial cell-to-cell communication: a new concept of antimicrobial chemotherapy breaks antibiotic resistance. Front Microbiol 2013; 4: 1-14

129 Sharif DI, Gallon J, Smith CJ, Dudley E. Quorum sensing in Cyanobacteria: N-octanoyl-homoserine lactone release and response, by the epilithic colonial cyanobacterium Gloeothece PCC6909. ISME J 2008; 2: 1171-1182

130 Romero M, Muro-Pastor AM, Otero A. Quorum sensing N-acylhomoserine lactone signals affect nitrogen fixation in the cyanobacterium Anabaena sp. PCC7120. FEMS Microbiol Lett 2011; 315: 101-108

131 Romero M, Diggle SP, Heeb S, Cámara M, Otero A. Quorum quenching activity in Anabaena sp. PCC 7120: identification of AiiC, a novel AHL-acylase. FEMS Microbiol Lett 2008; 280: 73-80

132 Clark BR, Engene N, Teasdale ME, Rowley DC, Matainaho T, Valeriote FA, Gerwick WH. Natural products chemistry and taxonomy of the marine cyanobacterium Blennothrix cantharidosmum. J Nat Prod 2008; 71: $1530-1537$

133 Dobretsov S, Teplitski M, Alagely A, Gunasekera SP, Paul VJ. Malyngolide from the cyanobacterium Lyngbya majuscula interferes with quorum sensing circuitry. Environ Microbiol Rep 2010; 2: 739-744

134 Ainslie RD, Barchi JJ, Kuniyoshi M, Moore RE, Myndersel JS. Structure of Malyngamide C. J Org Chem 1985; 50: 2859-2862

135 Kwan JC, Meickle T, Ladwa D, Teplitski M, Paul V, Luesch H. Lyngbyoic acid, a "tagged" fatty acid from a marine cyanobacterium, disrupts quorum sensing in Pseudomonas aeruginosa. Mol Biosyst 2011; 7: 1205-1216

136 Neuhof T, Schmieder P, Preussel K, Dieckmann R, Pham H, Bartl F, von Döhren $H$. Hassallidin A, a glycosylated lipopeptide with antifungal activity from the cyanobacterium Hassallia sp. J Nat Prod 2005; 68: 695-700

137 Neuhof T, Schmieder P, Seibold M, Preussel K, von Döhren H. Hassallidin B-second antifungal member of the Hassallidin family. Bioorg Med Chem Lett 2006; 16: 4220-4222

138 Vestola J, Shishido TK, Jokela J, Fewer DP, Aitio O, Permi P, Wahlsten M, Wang $H$, Rouhiainen L, Sivonen K. Hassallidins, antifungal glycolipopeptides, are widespread among cyanobacteria and are the end-product of a nonribosomal pathway. Proc Natl Acad Sci U S A 2014; 111 : E1909-E1917 
139 Neuhof T, Dieckmann R, von Döhren H, Preußel K, Seibold M, Schmieder P. Lipopeptides having pharmaceutical activity. Patent WO 2006/ 092313 A1; 2006

140 Bui TH, Wray V, Nimtz M, Fossen T, Preisitsch M, Schröder G, Wende K, Heiden SE, Mundt S. Balticidins A-D, antifungal hassallidin-like lipopeptides from the Baltic Sea cyanobacterium Anabaena cylindrica Bio33. J Nat Prod 2014; 77: 1287-1296

141 Frankmölle WP, Larsen LK, Caplan FR, Patterson GML, Knübel G, Levine $I A$, Moore RE. Antifungal cyclic peptides from the terrestrial bluegreen alga Anabaena laxa. I. Isolation and biological properties. J Antibiot (Tokyo) 1991; 45: 1451-1457

142 Frankmölle WP, Knübel G, Moore RE, Patterson GML. Antifungal cyclic peptides from the terrestrial blue-green alga Anabaena laxa. II. Structures of laxaphycins A, B, C, D and E. J Antibiot (Tokyo) 1992; 45: 1458-1466

143 Bonnard I, Rolland M, Francisco C, Banaigs B. Total structure and biological properties of laxaphycins A and B, cyclic lipopeptides from the marine cyanobacterium Lyngbya majuscula. Lett Pept Sci 1997; 4: 289-292

144 Bonnard I, Rolland M, Salmon JM, Debiton E, Barthomeuf C, Banaigs B. Total structure and inhibition of tumor cell proliferation of laxaphycins. J Med Chem 2007; 50: 1266-1279

145 Gbankoto A, Vigo J, Dramane K, Banaigs B, Aina E, Salmon JM. Cytotoxic effect of Laxaphycins $A$ and $B$ on human lymphoblastic cells (CCRF-CEM) using digitised videomicrofluorometry. In Vivo 2005; 19: $577-582$

146 Carter DC, Moore RE, Mynderse JS, Niemczura WP, Todd JS. Structure of majusculamide $\mathrm{C}$, a cyclic depsipeptide from Lyngbya majuscula. J Org Chem 1984; 49: 236-241

147 Moore RE, Mynderse JS. Majusculamide C. US Patent 4342751; 1982

148 Pettit GR, Hogan F, Xu JP, Tan R, Nogawa T, Cichacz Z, Pettit RK, Du J, Ye QH, Cragg GM, Herald CL, Hoard MS, Goswami A, Searcy J, Tackett L, Doubek DL, Williams L, Hooper JNA, Schmidt JM, Chapuis JC, Tackett $D N$, Craciunescu F. Antineoplastic agents. 536. New sources of naturally occurring cancer cell growth inhibitors from marine organisms, terrestrial plants, and microorganisms. J Nat Prod 2008; 71: 438-444

149 Ishibashi M, Moore RE, Patterson GML, Xu C, Clardy J. Scytophycins, cytotoxic and antimycotic agents from the cyanophyte Scytonema pseudohofmanni. J Org Chem 1986; 51: 5300-5306

150 Carmeli S, Moore RE, Patterson GML. Tolytoxin and new scytophycins from three species of Scytonema. J Nat Prod 1990; 53: 1533-1542

151 Patterson GML, Carmeli S. Biological effects of tolytoxin (6-hydroxy-7O-methyl-scytophycin b), a potent bioactive metabolite from cyanobacteria. Arch Microbiol 1992; 157: 406-410

152 Patterson GML, Smith CD, Kimura LH, Britton BA, Carmeli S. Action of tolytoxin on cell morphology, cytoskeletal organization, and actin polymerization. Cell Motil Cytoskeleton 1993; 24: 39-48

153 Smith CD, Carmeli S, Moore RE, Patterson GML. Scytophycins, novel microfilament-depolymerizing agents which circumvent P-glycoprotein-mediated multifrug resistance. Cancer Res 1993; 53: 1343-1347

154 Patterson GML, Bolis CM. Fungal cell-wall polysaccharides elicit an antifungal secondary metabolite (phytoalexin) in the cyanobacterium Scytonema ocellatum. J Phycol 1997; 33: 54-60

155 Moon SS, Chen JL, Moore RE, Patterson GML. Calophycin, a fungicidal cyclic decapeptide from the terrestrial blue-green alga Calothrix fusca. J Org Chem 1992; 57: 1097-1103

156 Singh IP, Milligan KE, Gerwick WH. Tanikolide, a toxic and antifungal lactone from the marine cyanobacterium Lyngbya majuscula. J Nat Prod 1999; 62: 1333-1335

157 Kanada RM, Taniguchi T, Ogasawara K. The First Synthesis of (+)-Tanikolide, a Toxic and Antifungal Lactone from the Marine Cyanobactetrium Lyngbya majuscula. Synlett 2000; 7: 1019-1021

158 Milligan KE, Marquez BL, Williamson RT, Gerwick WH. Lyngbyabellin B, a toxic and antifungal secondary metabolite from the marine cyanobacterium Lyngbya majuscula. J Nat Prod 2000; 63: 1440-1443

159 Kajiyama S, Kanzaki H, Kawazu K, Kobayashi A. Nostofungicidine, an antifungal lipopeptide from the field-grown terrestrial blue-green alga Nostoc commune. Tetrahedron Lett 1998; 39: 3737-3740

160 Jaki B, Zerbe 0 , Heilmann J, Sticher 0 . Two novel cyclic peptides with antifungal activity from the cyanobacterium Tolypothrix byssoidea (EAWAG 195). J Nat Prod 2001; 64: 154-158

161 Hagmann L, Jüttner F. Fischerellin A, a novel photosystem-II-inhibiting allelochemical of the cyanobacterium Fischerella muscicola with antifungal and herbicidal activity. Tetrahedron Lett 1996; 37: 6539-6542
162 MacMillan JB, Molinski TF. Majusculoic acid, a brominated cyclopropy fatty acid from a marine cyanobacterial mat assemblage. J Nat Prod 2005; 68: 604-606

163 MacMillan JB, Ernst-Russell MA, de Ropp JS, Molinski TF. Lobocyclamides A-C, lipopeptides from a cryptic cyanobacterial mat containing Lyngbya confervoides. J Org Chem 2002; 67: 8210-8215

164 Sonjoukhan R, Smltka TA, Doolin LE, Molloy RM, Debono M, Shaffer SA, Moore RE, Stewart JB, Patterson GML. Tjipanazoles, new antifungal agents from the blue-green alga Tolypothrix tjipanasensis. Tetrahedron 1991; 47: 7739-7750

165 Mundt S, Nowotny A, Mentel R, Lesnau A, Lindequist U. Antiviral activity of the cyanobacterium Microcystis aeruginosa SPH 01. Pharm Pharmacol Lett 1997; 7: 161-163

166 Zainuddin EN, Mundt S, Wegner U, Mentel R. Cyanobacteria a potential source of antiviral substances against influenza virus. Med Microbio Immunol 2002; 191: 181-182

167 Sharaf M, Amara A, Helmi S, Ballot A, Astani A, Schnitzler P. Molecular authentication and characterization of the antiherpetic activity of the cyanobacterium Arthrospira fusiformis. Pharmazie 2010; 65: 132-136

168 Lopes VR, Schmidtke M, Fernandes MH, Martins R, Vasconcelos V. Toxicology in L929 fibroblasts and inhibition of herpes simplex virus type 1 Kupka by estuarine cyanobacteria extracts. Toxicol In Vitro 2011; 25: 944-950

169 Gustafson KR, Cardellina JH 2nd, Fuller RW, Weislow OS, Kiser RF, Snader KM, Patterson GML, Boyd MR. AIDS-antiviral sulfolipids from cyanobacteria (blue-green algae). J Natl Cancer Inst 1989; 81: 1254 1258

170 Reshef V, Mizrachi E, Maretzki T, Silberstein C, Loya S, Hizi A, Carmeli S. New acylated sulfoglycolipids and digalactolipids and related known glycolipids from cyanobacteria with a potential to inhibit the reverse transcriptase of HIV-1. J Nat Prod 1997; 60: 1251-1260

171 Loya S, Reshef V, Mizrachi E, Silberstein C, Rachamim $Y$. The inhibition of the reverse transcriptase of HIV-1 by the natural sulfoglycolipids from cyanobacteria: contribution of different moieties to their high potency. J Nat Prod 1998; 61: 891-895

172 Boyd MR, Gustafson KR, McMahon JB, Shoemaker RH, O'Keefe BR, Mori T, Gulakowski RJ, Wu L, Rivera MI, Laurencot CM, Currens MJ, Cardellina JH 2nd, Buckheit RW jr., Nara PL, Pannell LK, Sowder RC 2nd, Henderson $L E$. Discovery of cyanovirin-N, a novel human immunodeficiency virus-inactivating protein that binds viral surface envelope glycoprotein gp120: potential applications to microbicide development. Antimicrob Agents Chemother 1997; 41: 1521-1530

173 Gustafson KR, Sowder RC 2nd, Henderson LE, Cardellina JH 2nd, McMahon JB, Rajamani U, Pannell LK, Boyd MR. Isolation, primary sequence determination, and disulfide bond structure of cyanovirin-N, an antiHIV (human immunodeficiency virus) protein from the cyanobacterium Nostoc ellipsosporum. Biochem Biophys Res Commun 1997; 228: $223-228$

174 Bolmstedt AJ, O'Keefe BR, Shenoy SR, McMahon JB, Boyd MR. Cyanovirin-N defines a new class of antiviral agent targeting $\mathrm{N}$-linked, highmannose glycans in an oligosaccharide-specific manner. Mol Pharmacol 2001; 59: 949-954

175 Bewley CA, Kiyonaka S, Hamachi I. Site-specific discrimination by cyanovirin-N for alpha-linked trisaccharides comprising the three arms of Man8 and Man9. J Mol Biol 2002; 322: 881-889

176 Botos I, O'Keefe BR, Shenoy SR, Cartner LK, Ratner DM, Seeberger PH, Boyd MR, Wlodawer A. Structures of the complexes of a potent antiHIV protein cyanovirin-N and high mannose oligosaccharides. J Biol Chem 2002; 277: 34336-34342

177 O'Keefe BR, Smee DF, Turpin JA, Saucedo CJ, Gustafson KR, Mori T, Blakeslee D, Buckheit R, Boyd MR. Potent anti-influenza activity of cyanovirin-N and interactions with viral hemagglutinin. Antimicrob Agents Chemother 2003; 47: 2518-2525

178 van der Meer FJUM, de Haan CAM, Schuurman NMP, Haijema BJ, Peumans WJ, Van Damme EJM, Delputte PL, Balzarini J, Egberink HF. Antiviral activity of carbohydrate-binding agents against Nidovirales in cell culture. Antiviral Res 2007; 76: 21-29

179 Patsalo V, Raleigh DP, Green DF. Rational and computational design of stabilized variants of cyanovirin-N that retain affinity and specificity for glycan ligands. Biochemistry 2011; 50: 10698-10712

180 Xiong S, Fan J, Kitazato K. The antiviral protein cyanovirin-N: the current state of its production and applications. Appl Microbiol Biotechnol 2010; 86: 805-812 
181 Huskens D, Vermeire K, Vandemeulebroucke E, Balzarini J, Schols D. Safety concerns for the potential use of cyanovirin-N as a microbicidal anti-HIV agent. Int J Biochem Cell Biol 2008; 40: 2802-2814

182 Huskens D, Férir G, Vermeire K, Kehr J, Balzarini J, Dittmann E, Schols D. Microvirin, a novel alpha(1,2)-mannose-specific lectin isolated from Microcystis aeruginosa, has anti-HIV-1 activity comparable with that of cyanovirin-N but a much higher safety profile. J Biol Chem 2010; 285: 24845-24854

183 Bokesch HR, O'Keefe BR, McKee TC, Pannell LK, Patterson GML, Gardella RS, Sowder RC 2nd, Turpin J, Watson K, Buckheit RW jr., Boyd MR. A potent novel anti-HIV protein from the cultured cyanobacterium Scytonema varium. Biochemistry 2003; 42: 2578-2584

184 Kanekiyo K, Lee JB, Hayashi K, Takenaka H, Hayakawa Y, Endo S, Hayashi $T$. Isolation of an antiviral polysaccharide, nostoflan, from a terrestrial cyanobacterium, Nostoc flagelliforme. J Nat Prod 2005; 68: 1037-1041

185 Wan F, Erickson KL. Serinol-derived malyngamides from an Australian cyanobacterium. J Nat Prod 1999; 62: 1696-1699

186 Zainuddin EN, Mentel R, Wray V, Jansen R, Nimtz M, Lalk M, Mundt S. Cyclic depsipeptides, ichthyopeptins A and B, from Microcystis ichthyoblabe. J Nat Prod 2007; 70: 1084-1088

187 Gupta DK, Kaur P, Leong ST, Tan LT, Prinsep MR, Chu JJH. Anti-Chikungunya viral activities of aplysiatoxin-related compounds from the marine cyanobacterium Trichodesmium erythraeum. Mar Drugs 2014; 12: $115-127$

188 Larsen LK, Moore RE, Patterson GML. beta-Carbolines from the bluegreen alga Dichothrix baueriana. J Nat Prod 1994; 57: 419-421

189 Knübel G, Larsen LK, Moore RE, Levine IA, Patterson GML. Cytotoxic, antiviral indolocarbazoles from a blue-green alga belonging to the Nostocaceae. J Antibiot 1990; 43: 1236-1239

190 Gademann K, Kobylinska J. Antimalarial natural products of marine and freshwater origin. Chem Rec 2009; 9: 187-198

191 Portmann C, Blom JF, Kaiser M, Brun R, Jüttner F, Gademann K. Isolation of aerucyclamides $C$ and $D$ and structure revision of microcyclamide 7806A: heterocyclic ribosomal peptides from Microcystis aeruginosa PCC 7806 and their antiparasite evaluation. J Nat Prod 2008; 71: 1891-1896

192 Portmann C, Sieber S, Wirthensohn S, Blom JF, Da Silva L, Baudat E, Kaiser M, Brun R, Gademann K. Balgacyclamides, antiplasmodial heterocyclic peptides from Microcystis aeruguinosa EAWAG 251. J Nat Prod 2014; 77: 557-562

193 Peña S, Scarone L, Medeiros A, Manta E, Comini M, Serra G. Synthesis of precursors and macrocycle analogs of aerucyclamides as anti-trypanosomal agents. MedChemComm 2012; 3: 1443-1448

194 Sanchez LM, Lopez D, Vesely BA, Della Togna G, Gerwick WH, Kyle DE, Linington RG. Almiramides A-C: discovery and development of a new class of leishmaniasis lead compounds. J Med Chem 2010; 53: 41874197

195 Linington RG, Sanchez LM. Novel Anti-Parasitic Compounds. Patent WO 2010/108164; 2010

196 Barbaras D, Kaiser M, Brun R, Gademann K. Potent and selective antiplasmodial activity of the cyanobacterial alkaloid nostocarboline and its dimers. Bioorg Med Chem Lett 2008; 18: 4413-4415

197 Simmons TL, Engene N, Ureña LD, Romero LI, Ortega-Barría E, Gerwick $L$, Gerwick WH. Viridamides A and B, Lipodepsipeptides with Antiprotozoal Activity from the Marine Cyanobacterium Oscillatoria nigroviridis. J Nat Prod 2008; 71: 1544-1550

198 Vining OB, Medina RA, Mitchell EA, Videau P, Li D, Serrill JD, Kelly JX, Gerwick WH, Proteau PJ, Ishmael JE, McPhail KL. Depsipeptide companeramides from a panamanian marine cyanobacterium associated with the coibamide producer. J Nat Prod 2015; 78: 413-420

199 Papendorf O, König GM, Wright AD. Hierridin B and 2, 4-dimethoxy-6heptadecylphenol, secondary metabolites from the cyanobacterium Phormidium ectocarpi with antiplasmodial activity. Phytochemistry 1998; 49: 2383-2386

200 Leão PN, Costa M, Ramos V, Pereira AR, Fernandes VC, Domingues VF, Gerwick WH, Vasconcelos VM, Martins R. Antitumor activity of hierridin B, a cyanobacterial secondary metabolite found in both filamentous and unicellular marine strains. PLoS One 2013; 8: e69562

201 Rickards RW, Rothschild JM, Willis AC, de Chazal NM, Kirk J, Kirk K, Saliba KJ, Smith GD. Calothrixins A and B, novel pentacyclic metabolites from Calothrix cyanobacteria with potent activity against malaria parasites and human cancer cells. Tetrahedron 1999; 55: 13513-13520

202 McPhail KL, Correa J, Linington RG, Gonzalez J, Ortega-Barría E, Capson $T L$, Gerwick WH. Antimalarial linear lipopeptides from a Panamanian strain of the marine cyanobacterium Lyngbya majuscula. J Nat Prod 2007; 70: 984-988

203 Tripathi A, Puddick J, Prinsep MR, Rottmann M, Tan LT. Lagunamides A and B: cytotoxic and antimalarial cyclodepsipeptides from the marine cyanobacterium Lyngbya majuscula. J Nat Prod 2010; 73: 1810-1814

204 Tripathi A, Puddick J, Prinsep MR, Rottmann M, Chan KP, Chen DY, Tan LT. Lagunamide C, a cytotoxic cyclodepsipeptide from the marine cyanobacterium Lyngbya majuscula. Phytochemistry 2011; 72: 23692375

205 Gutiérrez M, Tidgewell K, Capson TL, Engene N, Almanza A, Schemies J, Jung M, Gerwick WH. Malyngolide dimer, a bioactive symmetric cyclodepside from the panamanian marine cyanobacterium Lyngbya majuscula. J Nat Prod 2010; 73: 709-711

206 Linington RG, Gonzalez J, Ureña LD, Romero LI, Ortega-Barría E, Gerwick $W H$. Venturamides A and B: antimalarial constituents of the panamanian marine Cyanobacterium Oscillatoria sp. J Nat Prod 2007; 70: 397-401

207 Linington RG, Clark BR, Trimble EE, Almanza A, Ureña LD, Kyle DE, Gerwick WH. Antimalarial peptides from marine cyanobacteria: isolation and structural elucidation of gallinamide A. J Nat Prod 2009; 72: 1417

208 Miller B, Friedman AJ, Choi H, Hogan J, McCammon JA, Hook V, Gerwick $W H$. The marine cyanobacterial metabolite gallinamide $\mathrm{A}$ is a potent and selective inhibitor of human cathepsin L. J Nat Prod 2014; 77: $92-$ 99

209 Steinmann P, Keiser J, Bos R, Tanner M, Utzinger J. Schistosomiasis and water resources development: systematic review, meta-analysis, and estimates of people at risk. Lancet Infect Dis 2006; 6: 411-425

210 Chitsulo L, Engels D, Montresor A, Savioli L. The global status of schistosomiasis and its control. Acta Trop 2000; 77: 41-51

211 WHO. Report of the Scientific Working Group Meeting on Schistosomiasis. Geneva: WHO; 2005

212 Orjala J, Gerwick WH. Barbamide, a chlorinated metabolite with molluscicidal activity from the Caribbean cyanobacterium Lyngbya majuscula. J Nat Prod 1996; 59: 427-430

213 Sitachitta N, Rossi J, Roberts MA, Gerwick WH, Fletcher MD, Willis CL. Biosynthesis of the marine cyanobacterial metabolite barbamide. 1. Origin of the trichloromethyl group. J Am Chem Soc 1998; 120: $7131-7132$

214 Williamson RT, Sitachitta N, Gerwick WH. Biosynthesis of the marine cyanobacterial metabolite barbamide. 2: Elucidation of the origin of the thiazole ring by application of a new GHNMBC experiment. Tetrahedron Lett 1999; 40: 5175-5178

215 Sitachitta N, Márquez BL, Williamson RT, Rossi J, Roberts MA, Gerwick WH, Nguyen VA, Willis CL. Biosynthetic Pathway and Origin of the Chlorinated Methyl Group in Barbamide and Dechlorobarbamide, Metabolites from the Marine Cyanobacterium Lyngbya majuscula. Tetrahedron 2000; 56: 9103-9113

216 Flatt PM, O'Connell SJ, McPhail KL, Zeller G, Willis CL, Sherman DH, Gerwick $W H$. Characterization of the initial enzymatic steps of barbamide biosynthesis. J Nat Prod 2006; 69: 938-944

217 Galonic DP, Vaillancourt H, Walsh CT. Halogenation of unactivated carbon centers in natural product biosynthesis: trichlorination of leucine during barbamide biosynthesis. J Am Chem Soc 2006; 128: 3900-3901

218 Pereira AR, McCue CF, Gerwick WH. Cyanolide A, a glycosidic macrolide with potent Molluscicidal activity from the Papua New Guinea cyanobacterium Lyngbya bouillonii. J Nat Prod 2010; 73: 217-220

$219 \mathrm{Kim} \mathrm{H}$, Hong J. Total synthesis of cyanolide A and confirmation of its absolute configuration. Org Lett 2010; 12: 2880-2883

220 Hajare AK, Ravikumar V, Khaleel S, Bhuniya D, Reddy DS. Synthesis of molluscicidal agent cyanolide a macrolactone from D-(-)-pantolactone. J Org Chem 2011; 76: 963-966

221 Pabbaraja S, Satyanarayana K, Ganganna B, Yadav JS. Formal total synthesis of cyanolide A. J Org Chem 2011; 76: 1922-1925

222 Waldeck AR, Krische MJ. Total synthesis of cyanolide A in the absence of protecting groups, chiral auxiliaries, or premetalated carbon nucleophiles. Angew Chem Int Ed Engl 2013; 52: 4470-4473

223 Pereira AR, Etzbach L, Engene N, Müller R, Gerwick WH. Molluscicidal metabolites from an assemblage of Palmyra Atoll cyanobacteria. J Nat Prod 2011; 74: 1175-1181

224 Leão PN, Engene N, Antunes A, Gerwick WH, Vasconcelos V. The chemical ecology of cyanobacteria. Nat Prod Rep 2012; 29: 372-391

225 Turk $B$. Targeting proteases: successes, failures and future prospects. Nat Rev Drug Discov 2006; 5: 785-799 
226 Schmidt EW, Nelson JT, Rasko DA, Sudek S, Eisen JA, Haygood MG, Ravel $J$. Patellamide $A$ and $C$ biosynthesis by a microcin-like pathway in Prochloron didemni, the cyanobacterial symbiont of Lissoclinum patella. Proc Natl Acad Sci U S A 2005; 102: 7315-7320

227 Donia MS, Ravel J, Schmidt EW. A global assembly line for cyanobactins. Nat Chem Biol 2008; 4: 341-343

228 Ziemert N, Ishida K, Weiz A, Hertweck C, Dittmann E. Exploiting the natural diversity of microviridin gene clusters for discovery of novel tricyclic depsipeptides. Appl Environ Microbiol 2010; 76: 3568-3574
229 Kim EJ, Lee JH, Choi H, Pereira AR, Ban YH, Yoo YJ, Kim E, ParkJW, Sherman DH, Gerwick WH, Yoon YJ. Heterologous production of 4-O-demethylbarbamide, a marine cyanobacterial natural product. Org Lett 2012; 14: 5824-5827

230 Ongley SE, Bian X, Zhang Y, Chau R, Gerwick WH, Müller R, Neilan BE. High-titer heterologous production in E. coli of lyngbyatoxin, a protein kinase $C$ activator from an uncultured marine cyanobacterium. ACS Chem Biol 2013; 8: 1888-1893 